\title{
Kinetics and Mechanism of the Anilinolysis of Bis(aryl) Chlorophosphates in Acetonitrile
}

\author{
Hasi Rani Barai and Hai Whang Lee* \\ Department of Chemistry, Inha University, Incheon 402-751, Korea. *E-mail: hwlee@inha.ac.kr \\ Received April 19, 2011, Accepted April 22, 2011
}

\begin{abstract}
The nucleophilic substitution reactions of bis(Y-aryl) chlorophosphates (1) with substituted anilines and deuterated anilines are investigated kinetically in acetonitrile at $35.0^{\circ} \mathrm{C}$. The kinetic results of 1 are compared with those of Y-aryl phenyl chlorophosphates (2). The substrate $\mathbf{1}$ has one more identical substituent Y compared to substrate 2 . The cross-interaction between $\mathrm{Y}$ and $\mathrm{Y}$, due to additional substituent $\mathrm{Y}$, is significant enough to result in the change of the sign of cross-interaction constant (CIC) from negative $\rho_{\mathrm{XY}}=-1.31$ (2) to positive $\rho_{\mathrm{XY}}=+1.91$ (1), indicating the change of reaction mechanism from a concerted $\mathrm{S}_{\mathrm{N}} 2(\mathbf{2})$ to a stepwise mechanism with a rate-limiting leaving group departure from the intermediate (1). The deuterium kinetic isotope effects (DKIEs) involving deuterated anilines $\left(\mathrm{XC}_{6} \mathrm{H}_{4} \mathrm{ND}_{2}\right)$ show secondary inverse, $k_{\mathrm{H}} / k_{\mathrm{D}}=0.61-0.87$. The DKIEs invariably increase as substituent $\mathrm{X}$ changes from electron-donating to electron-withdrawing, while invariably decrease as substituent $Y$ changes from electron-donating to electron-withdrawing. A stepwise mechanism with a rate-limiting bond breaking involving a predominant backside attack is proposed on the basis of positive sign of $\rho_{\mathrm{XY}}$ and secondary inverse DKIEs.
\end{abstract}

Key Words : Phosphoryl transfer reaction, Anilinolysis, Bis(aryl) chlorophosphates, Deuterium kinetic isotope effects, Cross-interaction constant

\section{Introduction}

The first work of this lab on the phosphoryl transfer reaction was the kinetic study on the anilinolysis of Y-aryl phenyl chlorophosphates $\left[2 ;\left(\mathrm{YC}_{6} \mathrm{H}_{4} \mathrm{O}\right)(\mathrm{PhO}) \mathrm{P}(=\mathrm{O}) \mathrm{Cl}\right]$ in acetonitrile. ${ }^{\text {1a }}$ A concerted mechanism with a late, productlike transition state (TS) was proposed on the basis of a large negative cross-interaction constant (CIC; $\left.\rho_{\mathrm{XY}}=-1.31\right)$ and relatively large secondary inverse deuterium kinetic isotope effects (DKIEs) with deuterated anilines $\left(\mathrm{XC}_{6} \mathrm{H}_{4} \mathrm{ND}_{2}\right)\left(k_{\mathrm{H}} / k_{\mathrm{D}}\right.$ $=0.61-0.87)$. Continuing the studies on phosphoryl transfer reactions (anilinolysis, ${ }^{1}$ pyridinolysis, ${ }^{2}$ benzylaminolysis, ${ }^{3}$ and theoretical study $\left.{ }^{4}\right)$, the nucleophilic substitution reactions of bis $(\mathrm{Y}$-aryl $)$ chlorophosphates $\left[\mathbf{1} ;\left(\mathrm{YC}_{6} \mathrm{H}_{4} \mathrm{O}\right)_{2} \mathrm{P}(=\mathrm{O}) \mathrm{Cl}\right]$ with substituted anilines and deuterated anilines are investigated kinetically in $\mathrm{MeCN}$ at $35.0 \pm 0.1{ }^{\circ} \mathrm{C}$ (Scheme 1). The aim of this work is to study the dual substituent effects on the reaction rate and mechanism where the substrate has the very same substituent $\mathrm{Y}$ in each phenyl ring, and to gain further information into the phosphoryl transfer reactions, as well as to compare the reactivity, mechanism and DKIEs of the anilinolyses of chlorophosphate substrates, $(\mathrm{RO})_{1}$ $(\mathrm{RO})_{2} \mathrm{P}(=\mathrm{O})$ Cl-type: Y-aryl phenyl (2), ${ }^{1 \mathrm{a}}$ Y-aryl ethyl [3;

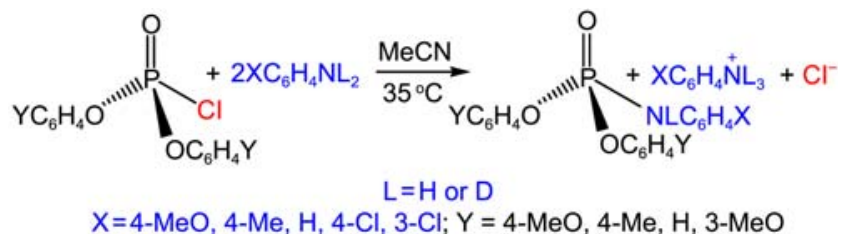

Scheme 1. The studied reaction system.
$\left.\left(\mathrm{YC}_{6} \mathrm{H}_{4} \mathrm{O}\right)(\mathrm{EtO}) \mathrm{P}(=\mathrm{O}) \mathrm{Cl}\right],{ }^{1 \mathrm{f}}$ diethyl $\left[4 ; \quad(\mathrm{EtO})_{2} \mathrm{P}(=\mathrm{O}) \mathrm{Cl}\right],{ }^{1 \mathrm{~g}}$ and dimethyl $\left[\mathbf{5} ;(\mathrm{MeO})_{2} \mathrm{P}(=\mathrm{O}) \mathrm{Cl}\right]^{1 \mathrm{~g}}$ chlorophosphates. Herein, the difference between $\mathbf{1}$ and $\mathbf{2}$ is nothing but one substituent $\mathrm{Y}$ in the other phenyl ring, i.e., substrate $\mathbf{1}$ has one more same substituent Y compared to substrate 2. The numbering of the substrates (1-5) follows the sequence of the size of the two ligands, $(\mathrm{RO})_{1}$ and $(\mathrm{RO})_{2}$.

\section{Results and Discussion}

The observed pseudo-first-order rate constants $\left(k_{\text {obsd }}\right)$ were found to follow eq. (1) for all of the reactions under pseudofirst-order conditions with a large excess of aniline nucleophile. The $k_{0}$ values were negligible $\left(k_{0}=0\right)$ in acetonitrile. The second-order rate constants $\left(k_{2}\right)$ were determined for at least five concentrations of anilines. The linear plots of eq. (1) suggest that there is no base-catalysis or noticeable side reactions and that the overall reaction is described by Scheme 1 .

$$
k_{\text {obsd }}=k_{0}+k_{2}\left[\mathrm{XC}_{6} \mathrm{H}_{4} \mathrm{NH}_{2}\right]
$$

The second-order rate constants $\left(k_{2}\right)$ are summarized in Table 1 , together with the selectivity parameters, $\rho_{\mathrm{X}}, \beta_{\mathrm{X}}, \rho_{\mathrm{Y}}$, and $\rho_{\mathrm{XY}}{ }^{7}$ The $\mathrm{p} K_{\mathrm{a}}$ values of the anilines in water are used to obtain the Brönsted $\beta_{\mathrm{X}}$ values in $\mathrm{MeCN}$, and this procedure are justified experimentally and theoretically. ${ }^{8}$ The $\rho_{\mathrm{Y}}$ values are calculated from the plots of $\log k_{2}$ against $\sigma_{\mathrm{Y}}$ although all of the studied substrates contain the two Y-substituted phenyl rings with same substituent Y. Figures 1, 2, and 3 show the Hammett $\left(\log k_{2}\right.$ vs $\left.\sigma_{\mathrm{X}}\right)$, Brönsted [log $k_{2} v s$ $\left.\mathrm{p} K_{\mathrm{a}}(\mathrm{X})\right]$, and Hammett (log $\left.k_{2} v s \sigma_{\mathrm{Y}}\right)$ plots, respectively. 
Table 1. The second-order rate constants $\left(k_{2} \times 10^{4} / \mathrm{M}^{-1} \mathrm{~s}^{-1}\right)$ and selectivity parameters ${ }^{a}\left(\rho_{\mathrm{X}}, \beta_{\mathrm{X}}, \rho_{\mathrm{Y}}\right.$, and $\left.\rho_{\mathrm{XY}}\right)$ of the reactions of 1 [bis(Y-aryl) chlorophosphates] with $\mathrm{XC}_{6} \mathrm{H}_{4} \mathrm{NH}_{2}$ in $\mathrm{MeCN}$ at $35.0{ }^{\circ} \mathrm{C}$

\begin{tabular}{cccccc}
\hline $\mathrm{X} \backslash \mathrm{Y}$ & $4-\mathrm{MeO}$ & $4-\mathrm{Me}$ & $\mathrm{H}$ & $3-\mathrm{MeO}$ & $\rho_{Y}{ }^{d}$ \\
\hline $4-\mathrm{MeO}$ & $50.2 \pm 0.7$ & $57.7 \pm 0.4$ & $65.9 \pm 0.2$ & $73.8 \pm 1.4$ & $0.41 \pm 0.01$ \\
$4-\mathrm{Me}$ & $17.2 \pm 0.1$ & $20.7 \pm 0.3$ & $22.4 \pm 0.6$ & $32.0 \pm 0.1$ & $0.62 \pm 0.04$ \\
$\mathrm{H}$ & $3.07 \pm 0.01$ & $4.15 \pm 0.02$ & $4.43 \pm 0.02$ & $8.24 \pm 0.12$ & $0.96 \pm 0.08$ \\
$4-\mathrm{Cl}$ & $0.277 \pm 0.002$ & $0.409 \pm 0.002$ & $0.568 \pm 0.007$ & $1.10 \pm 0.03$ & $1.43 \pm 0.06$ \\
$3-\mathrm{Cl}$ & $0.0751 \pm 0.0001$ & $0.119 \pm 0.004$ & $0.202 \pm 0.001$ & $0.334 \pm 0.003$ & $1.61 \pm 0.02$ \\
$-\rho_{\mathrm{X}}{ }^{c}$ & $4.43 \pm 0.02$ & $4.21 \pm 0.03$ & $3.93 \pm 0.06$ & $3.67 \pm 0.02$ & $\rho_{\mathrm{XY}}=$ \\
$\beta_{\mathrm{X}}{ }^{c}$ & $1.56 \pm 0.07$ & $1.48 \pm 0.07$ & $1.38 \pm 0.10$ & $1.29 \pm 0.04$ & $1.91 \pm 0.05^{e}$ \\
\hline
\end{tabular}

${ }^{a}$ The $\sigma$ values were taken from ref 5 . The $\mathrm{p} K_{\mathrm{a}}$ values of X-anilines in water were taken from ref $6 .{ }^{b}$ Correlation coefficient, $r \geq 0.999$. ${ }^{c} r \geq 0.997$. ${ }^{d} r \geq 0.924 .{ }^{e} r=0.998$.

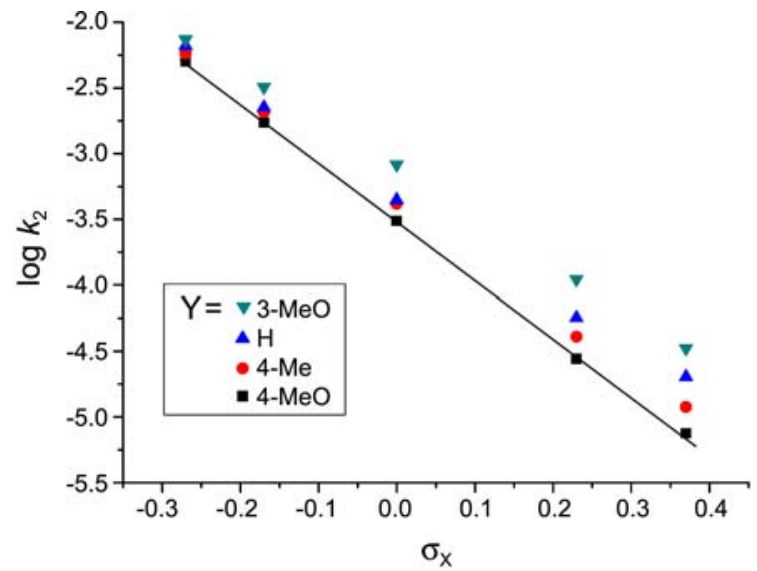

Figure 1. The Hammett plots $\left(\log k_{2} v s \sigma_{\mathrm{X}}\right)$ of the reactions of 1 [bis(Y-aryl) chlorophosphates] with $\mathrm{XC}_{6} \mathrm{H}_{4} \mathrm{NH}_{2}$ in $\mathrm{MeCN}$ at 35.0 ${ }^{\circ} \mathrm{C}$.

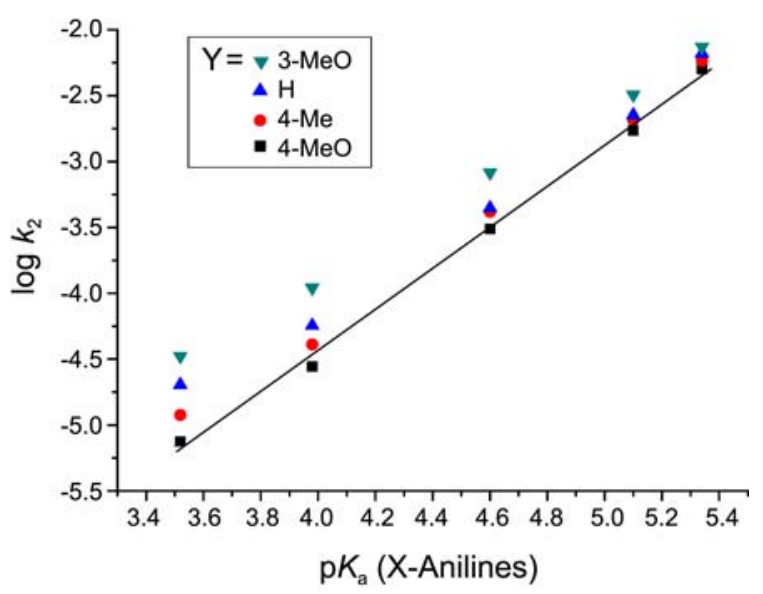

Figure 2. The Brönsted plots $\left[\log k_{2} v s \mathrm{p} K_{\mathrm{a}}(\mathrm{X})\right]$ of the reactions of 1 [bis(Y-aryl) chlorophosphates] with $\mathrm{XC}_{6} \mathrm{H}_{4} \mathrm{NH}_{2}$ in $\mathrm{MeCN}$ at 35.0 ${ }^{\circ} \mathrm{C}$.

The substituent effects on the reaction rates are compatible with a typical nucleophilic substitution reaction. The stronger nucleophile leads to the faster rate with positive charge development at the nucleophilic nitrogen atom $\left(\rho_{\mathrm{X}}<0\right.$ and $\beta_{\mathrm{X}}>0$ ) and a more electron-withdrawing substituent $\mathrm{Y}$ in the substrate leads to the faster rate with negative charge development at the reaction center phosphorus atom $\left(\rho_{\mathrm{Y}}>0\right)$ in the TS. The magnitudes of $\rho_{\mathrm{X}}$ and $\beta_{\mathrm{X}}$ values are relatively

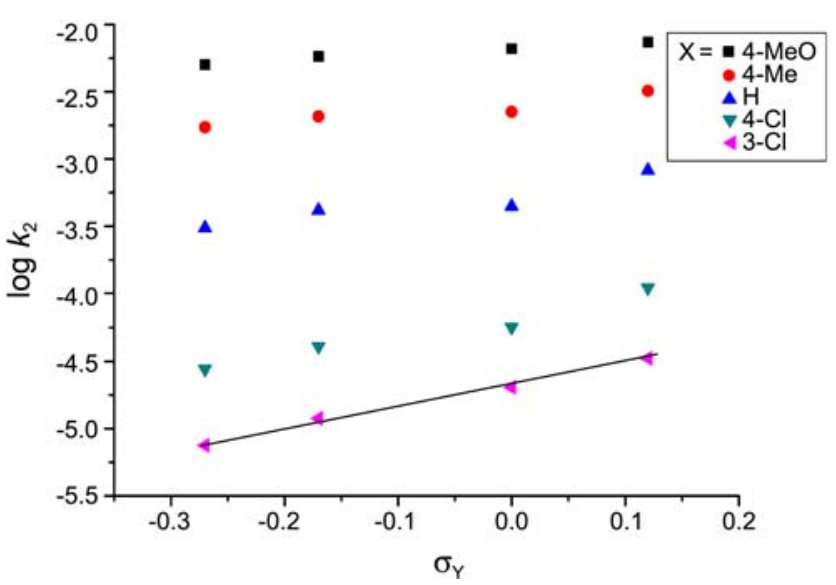

Figure 3. The Hammett plots $\left(\log k_{2} v s \sigma_{\mathrm{Y}}\right)$ of the reactions of 1 [bis(Y-aryl) chlorophosphates] with $\mathrm{XC}_{6} \mathrm{H}_{4} \mathrm{NH}_{2}$ in $\mathrm{MeCN}$ at 35.0 ${ }^{\circ} \mathrm{C}$.

large and comparable with those of 2 . The magnitudes of $\rho_{\mathrm{Y}}$ values are approximately two times greater than those of $\mathbf{2}$. However, the variation tendencies of $\rho_{\mathrm{X}}$ and $\rho_{\mathrm{Y}}$ values for substituents $\mathrm{Y}$ and $\mathrm{X}$ variations, respectively, are opposite to those of 2 .

When both the nucleophile and substrate have only one substituent $\mathrm{X}$ and $\mathrm{Y}$, respectively, a Taylor series expansion of $\log k_{\mathrm{XY}}$ around $\sigma_{\mathrm{X}}=\sigma_{\mathrm{Y}}=0$ leads to eq. (2a). ${ }^{9}$ Herein, pure second- (e.g., $\rho_{\mathrm{XX}} \sigma_{\mathrm{X}}^{2}$ or $\rho_{\mathrm{YY}} \sigma_{\mathrm{Y}}^{2}$ ), third- (e.g., $\rho_{\mathrm{XXY}} \sigma_{\mathrm{X}}^{2} \sigma_{\mathrm{Y}}$ or $\rho_{\mathrm{XYY}} \sigma_{\mathrm{X}} \sigma_{\mathrm{Y}}^{2}$ ), and higher-derivative terms (e.g., $\rho_{\mathrm{XXXY}} \sigma_{\mathrm{X}}{ }^{3} \sigma_{\mathrm{Y}}$ or $\rho_{\mathrm{XXYY}} \sigma_{\mathrm{X}}^{2} \sigma_{\mathrm{Y}}^{2}$, etc) are neglected since they are normally too small to be taken into account. The sign of the CIC $\left(\rho_{\mathrm{XY}}\right)$ is negative in a normal $\mathrm{S}_{\mathrm{N}} 2$ reaction (or in a stepwise reaction with a rate-limiting bond formation), and positive in a stepwise reaction with a rate-limiting leaving group expulsion from the intermediate. ${ }^{7}$ The magnitude of the CIC is inversely proportional to the distance between $\mathrm{X}$ and $\mathrm{Y}$ through the reaction center; the tighter the TS, the greater the magnitude of the CIC. ${ }^{7}$

$$
\begin{gathered}
\log \left(k_{\mathrm{XY}} / k_{\mathrm{HH}}\right)=\rho_{\mathrm{X}} \sigma_{\mathrm{X}}+\rho_{\mathrm{Y}} \sigma_{\mathrm{Y}}+\rho_{\mathrm{XY}} \sigma_{\mathrm{X}} \sigma_{\mathrm{Y}} \\
\rho_{\mathrm{XY}}=\partial^{2} \log \left(k_{\mathrm{XY}} / k_{\mathrm{HH}}\right) / \partial \sigma_{\mathrm{X}} \partial \sigma_{\mathrm{Y}}=\partial \rho_{\mathrm{X}} / \partial \sigma_{\mathrm{Y}}=\partial \rho_{\mathrm{Y}} / \partial \sigma_{\mathrm{X}}
\end{gathered}
$$

In the present work, the modified eq. (3) is introduced in which the cross-interaction between $\mathrm{Y}$ (in one phenyl ring) and Y (in the other phenyl ring) is included, since all of the 


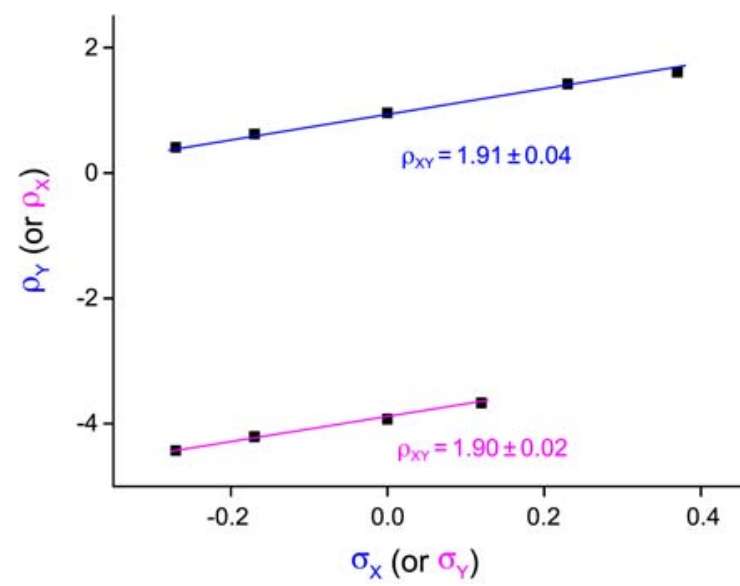

Figure 4. Determination of $\rho_{\mathrm{XY}}$ according to eq. (2b) and (3a), $\rho_{\mathrm{XY}}$ $=\partial \rho_{\mathrm{X}} / \partial \sigma_{\mathrm{Y}}=\partial \rho_{\mathrm{Y}} / \partial \sigma_{\mathrm{X}}$. The plots of $\rho_{\mathrm{X}} v s \sigma_{\mathrm{Y}}$ and $\rho_{\mathrm{Y}} v s \sigma_{\mathrm{X}}$ of the reactions of 1 [bis(Y-aryl) chlorophosphates] with $\mathrm{XC}_{6} \mathrm{H}_{4} \mathrm{NH}_{2}$ in $\mathrm{MeCN}$ at $35.0{ }^{\circ} \mathrm{C}$. The value of $\rho_{\mathrm{XY}}=1.91 \pm 0.05(r=0.998)$ is obtained by multiple regression.

studied substrates have identical substituent $\mathrm{Y}$ in each phenyl ring. The third and fourth term on the right-side of eq. (3a) indicate the cross-interaction between $\mathrm{X}$ and two $\mathrm{Y}$, and $\mathrm{Y}$ (in one phenyl ring) and $\mathrm{Y}$ (in the other phenyl ring), respectively. The value of $\rho_{\mathrm{YY}}$ reflects the cross-interaction between the two substituents, Y and Y, in the TS. Herein, Y and $Y$ denote the substituent in each phenyl ring in the same substrate. In eq. (3a), pure second-, third-, and higherderivative terms are not considered as in eq. (2). The values of $\rho_{\mathrm{X}}, \rho_{\mathrm{Y}}, \rho_{\mathrm{XY}}$, and $\rho_{\mathrm{YY}}$ obtained by multiple regression are described in eq. (3b). The values of $\rho_{\mathrm{X}}=-3.93$ when $\mathrm{Y}=\mathrm{H}$ $\left(\sigma_{\mathrm{Y}}=0\right)$ and $\rho_{\mathrm{Y}}=0.96$ when $\mathrm{X}=\mathrm{H}\left(\sigma_{\mathrm{X}}=0\right)$ in Table 1 are not far from those of eq. (3b), $\rho_{\mathrm{X}}=-3.91$ and $\rho_{\mathrm{Y}}=1.08$. As a matter of course, the value of $\rho_{\mathrm{XY}}=1.91$ (Fig. 4) has the same value both in eq. (2) and eq. (3b) since $\rho_{\mathrm{XY}}$ is defined as $\partial \rho_{\mathrm{X}} / \partial \sigma_{\mathrm{Y}}=\partial \rho_{\mathrm{Y}} / \partial \sigma_{\mathrm{X}}$. Note that the $\rho_{\mathrm{YY}}$ value is as large as 0.90 , i.e., nearly half of the value of $\rho_{\mathrm{XY}}$. To understand the contribution of pure second-derivative term $\left(\rho_{\mathrm{YY}} \sigma_{\mathrm{Y}}{ }^{2}\right)$ on the reaction rate, eq. (3a) is applied to the anilinolysis of $\mathbf{2}$ in which the substrate has only one substituent $\mathrm{Y}$, and eq. (3c) is obtained. Herein, the $\rho_{\mathrm{YY}} \sigma_{\mathrm{Y}}^{2}$ is pure second-derivative term and reflects $\mathrm{Y}-\mathrm{Y}$ self-interaction. The values of $\rho_{\mathrm{X}}=$ -3.74 when $\mathrm{Y}=\mathrm{H}\left(\sigma_{\mathrm{Y}}=0\right)^{1 \mathrm{a}}$ and $\rho_{\mathrm{Y}}=0.54$ when $\mathrm{X}=\mathrm{H}\left(\sigma_{\mathrm{X}}\right.$ $=0)^{1 \mathrm{a}}$ are close to those of eq. (3c), $\rho_{\mathrm{X}}=-3.76$ and $\rho_{\mathrm{Y}}=0.52$. In eq. ( $3 \mathrm{c})$, the $\rho_{\mathrm{YY}}=0.02$ implies that there is little $\mathrm{Y}-\mathrm{Y}$ selfinteraction in the TS, i.e., too small to be taken into account as expected. ${ }^{10}$ These results support that the value of $\rho_{\mathrm{YY}}=$ 0.90 in eq. (3b) is absolutely attributed to the crossinteraction between $\mathrm{Y}$ and $\mathrm{Y}$ in each phenyl ring.

$\log \left(k_{\mathrm{XY}} / k_{\mathrm{HH}}\right)=\rho_{\mathrm{X}} \sigma_{\mathrm{X}}+\rho_{\mathrm{Y}} \sigma_{\mathrm{Y}}+\rho_{\mathrm{XY}} \sigma_{\mathrm{X}} \sigma_{\mathrm{Y}}+\rho_{\mathrm{YY}} \sigma_{\mathrm{Y}} \sigma_{\mathrm{Y}}$

$\log \left(k_{\mathrm{XY}} / k_{\mathrm{HH}}\right)=-3.91 \sigma_{\mathrm{X}}+1.08 \sigma_{\mathrm{Y}}+1.91 \sigma_{\mathrm{X}} \sigma_{\mathrm{Y}}+0.90 \sigma_{\mathrm{Y}} \sigma_{\mathrm{Y}}(3 \mathrm{~b})$

$\log \left(k_{\mathrm{XY}} / k_{\mathrm{HH}}\right)=-3.76 \sigma_{\mathrm{X}}+0.52 \sigma_{\mathrm{Y}}-1.31 \sigma_{\mathrm{X}} \sigma_{\mathrm{Y}}+0.02 \sigma_{\mathrm{Y}}^{2}$

The difference between $\mathbf{1}$ and $\mathbf{2}$ is one substituent $\mathrm{Y}$ in the other phenyl ring, i.e., substrate $\mathbf{1}$ has one more same substituent $\mathrm{Y}$ in the other phenyl ring compared to sub- strate 2. It is evident that the cross-interaction, $\rho_{\mathrm{YY}} \sigma_{\mathrm{Y}} \sigma_{\mathrm{Y}}=$ $0.90 \sigma_{\mathrm{Y}} \sigma_{\mathrm{Y}}$, between the two substituents, $\mathrm{Y}$ and $\mathrm{Y}$, in $\mathbf{1}$ is really significant. An additional substituent $Y$ to the other phenyl ring actually affects the values of $\rho_{\mathrm{X}}$ and $\rho_{\mathrm{Y}}$. Although the overall magnitudes of $\rho_{\mathrm{X}}$ and $\rho_{\mathrm{Y}}$ values of 1 are comparable to those of $2\left[\rho_{\mathrm{X}}=-1.29\right.$ to -1.56 (1) and -1.24 to $-1.68(2) ; \rho_{\mathrm{Y}}=(0.41-1.61) / 2=0.21-0.81(1)$ and $0.22-0.87(2)]$, the variation tendencies of the $\rho_{\mathrm{X}}$ and $\rho_{\mathrm{Y}}$ values of 1 are completely opposite to those of $\mathbf{2}$. In $\mathbf{2}$, the values of $\rho_{\mathrm{X}}$ and $\rho_{\mathrm{Y}}$ invariably decrease $\left(\partial \rho_{\mathrm{X}}<0\right.$ and $\partial \rho_{\mathrm{Y}}<$ $0)$ as the substituent $Y$ and $X$ change from electron-donating to electron-withdrawing $\left(\partial \sigma_{\mathrm{Y}}>0\right.$ and $\left.\partial \sigma_{\mathrm{X}}>0\right): \rho_{\mathrm{X}}=-3.42$ $(\mathrm{Y}=4-\mathrm{MeO})>-3.55(4-\mathrm{Me})>-3.74(\mathrm{H})>-4.09(4-\mathrm{Cl})>-4.63$ $(4-\mathrm{CN})$ and $\rho_{\mathrm{Y}}=0.87(\mathrm{X}=4-\mathrm{MeO})>0.77(4-\mathrm{Me})>0.54(\mathrm{H})$ $>0.22(4-\mathrm{Cl}) .{ }^{1 \mathrm{a}}$ As a result, the negative sign with relatively large magnitude of $\rho_{\mathrm{XY}}(=-1.31 \pm 0.20$ with $r=0.998)$ was obtained according to eq. (2b); $\rho_{\mathrm{XY}}=\partial \rho_{\mathrm{X}} / \partial \sigma_{\mathrm{Y}}=\partial \rho_{\mathrm{Y}} / \partial \sigma_{\mathrm{X}}=$ $(-) /(+)<0 .{ }^{1 \mathrm{a}}$ On the contrary, in 1 , the values of $\rho_{\mathrm{X}}$ and $\rho_{\mathrm{Y}}$ invariably increase $\left(\partial \rho_{\mathrm{X}}>0\right.$ and $\left.\partial \rho_{\mathrm{Y}}>0\right)$ as $\mathrm{Y}$ and $\mathrm{X}$ change from electron-donating to electron-withdrawing $\left(\partial \sigma_{\mathrm{Y}}>0\right.$ and $\left.\partial \sigma_{\mathrm{X}}>0\right): \rho_{\mathrm{X}}=-4.43(\mathrm{Y}=4-\mathrm{MeO})<-4.21(4-\mathrm{Me})<$ $-3.93(\mathrm{H})<-3.67(3-\mathrm{MeO})$ and $\rho_{\mathrm{Y}}=0.41(\mathrm{X}=4-\mathrm{MeO})<$ $0.62(4-\mathrm{Me})<0.96(\mathrm{H})<1.43(4-\mathrm{Cl})<1.61(3-\mathrm{Cl})$. Thus, the positive sign with great magnitude of $\rho_{\mathrm{XY}}=+1.91 \pm 0.05(r$ $=0.998)$ is obtained according to eqs. (2) and (3a); $\rho_{\mathrm{XY}}=$ $\partial \rho_{\mathrm{X}} / \partial \sigma_{\mathrm{Y}}=\partial \rho_{\mathrm{Y}} / \partial \sigma_{\mathrm{X}}=(+) /(+)>0$. Thus, the authors suggest that an additional substituent $\mathrm{Y}$ to the other phenyl ring changes the reaction mechanism from a concerted $S_{N} 2$ in 2 to a stepwise with a rate-limiting leaving group departure from the intermediate in 1on the basis of the change of sign of $\rho_{\mathrm{XY}}$ from negative $\left(\rho_{\mathrm{XY}}=-1.31\right.$ in 2$)$ to positive $\left(\rho_{\mathrm{XY}}=\right.$ +1.91 in $\mathbf{1})$.

In addition to the CICs, the DKIEs $\left(k_{\mathrm{H}} / k_{\mathrm{D}}\right)$ are also one of the strong tools to clarify the reaction mechanism. When partial deprotonation of the aniline occurs in a rate-limiting step by hydrogen bonding, the $k_{\mathrm{H}} / k_{\mathrm{D}}$ values are greater than unity, primary normal $\left(k_{\mathrm{H}} / k_{\mathrm{D}}>1.0\right) .{ }^{11}$ In contrast, the DKIEs can only be secondary inverse $\left(k_{\mathrm{H}} / k_{\mathrm{D}}<1.0\right)$ in a normal $\mathrm{S}_{\mathrm{N}} 2$ reaction, since the $\mathrm{N}-\mathrm{H}(\mathrm{D})$ vibrational frequencies invariably

Table 2. The DKIEs $\left(k_{\mathrm{H}} / k_{\mathrm{D}}\right)$ for the reactions of 1 [bis(Y-aryl) chlorophosphates] with $\mathrm{XC}_{6} \mathrm{H}_{4} \mathrm{NH}_{2}\left(\mathrm{D}_{2}\right)$ in $\mathrm{MeCN}$ at $35.0^{\circ} \mathrm{C}$

\begin{tabular}{ccccc}
\hline $\mathrm{X}$ & $\mathrm{Y}$ & $k_{\mathrm{H}} \times 10^{4} / \mathrm{M}^{-1} \mathrm{~s}^{-1}$ & $k_{\mathrm{D}} \times 10^{4} / \mathrm{M}^{-1} \mathrm{~s}^{-1}$ & $k_{\mathrm{H}} / k_{\mathrm{D}}$ \\
\hline & $4-\mathrm{MeO}$ & $50.2 \pm 0.7$ & $68.3 \pm 0.3$ & $0.74 \pm 0.01^{a}$ \\
$4-\mathrm{MeO}$ & $4-\mathrm{Me}$ & $57.7 \pm 0.4$ & $88.7 \pm 0.4$ & $0.65 \pm 0.01$ \\
& $\mathrm{H}$ & $65.9 \pm 0.2$ & $115 \pm 1$ & $0.58 \pm 0.01$ \\
& $3-\mathrm{MeO}$ & $73.8 \pm 1.4$ & $134 \pm 1$ & $0.55 \pm 0.01$ \\
\hline & $4-\mathrm{MeO}$ & $3.07 \pm 0.01$ & $3.56 \pm 0.01$ & $0.86 \pm 0.01$ \\
$\mathrm{H}$ & $4-\mathrm{Me}$ & $4.45 \pm 0.02$ & $5.02 \pm 0.02$ & $0.83 \pm 0.01$ \\
& $\mathrm{H}$ & $4.43 \pm 0.02$ & $5.74 \pm 0.01$ & $0.77 \pm 0.01$ \\
& $3-\mathrm{MeO}$ & $8.24 \pm 0.12$ & $11.3 \pm 0.01$ & $0.73 \pm 0.01$ \\
\hline & $4-\mathrm{MeO}$ & $0.277 \pm 0.002$ & $0.283 \pm 0.002$ & $0.98 \pm 0.01$ \\
$4-\mathrm{Cl}$ & $4-\mathrm{Me}$ & $0.409 \pm 0.002$ & $0.428 \pm 0.001$ & $0.96 \pm 0.01$ \\
& $\mathrm{H}$ & $0.568 \pm 0.007$ & $0.596 \pm 0.001$ & $0.95 \pm 0.01$ \\
& $3-\mathrm{MeO}$ & $1.10 \pm 0.03$ & $1.17 \pm 0.01$ & $0.94 \pm 0.03$ \\
\hline
\end{tabular}

${ }^{a}$ Standard error $\left\{=1 / k_{\mathrm{D}}\left[\left(\Delta k_{\mathrm{H}}\right)^{2}+\left(k_{\mathrm{H}} / k_{\mathrm{D}}\right)^{2} \times\left(\Delta k_{\mathrm{D}}\right)^{2}\right]^{1 / 2}\right\}$ from ref 12 . 
increase upon going to the TS because of an increase in steric congestion in the bond-making process. ${ }^{11}$ In the present work, the DKIEs are all secondary inverse, $k_{\mathrm{H}} / k_{\mathrm{D}}<$ 1.0, (Table 2), indicating that partial deprotonation of the aniline does not occur in a rate-limiting step by hydrogen bonding. The DKIEs invariably increase as substituent $\mathrm{X}$ changes from electron-donating to electron-withdrawing, $k_{\mathrm{H}} / k_{\mathrm{D}}(\mathrm{X}=4-\mathrm{MeO})<k_{\mathrm{H}} / k_{\mathrm{D}}(\mathrm{H})<k_{\mathrm{H}} / k_{\mathrm{D}}(4-\mathrm{Cl})$ (contrary to 2 ), while invariably decrease as substituent $\mathrm{Y}$ changes from electron-donating to electron-withdrawing, $k_{\mathrm{H}} / k_{\mathrm{D}}(\mathrm{Y}=4$ $\mathrm{MeO})>k_{\mathrm{H}} / k_{\mathrm{D}}(4-\mathrm{Me})>k_{\mathrm{H}} / k_{\mathrm{D}}(\mathrm{H})>k_{\mathrm{H}} / k_{\mathrm{D}}(3-\mathrm{MeO})$.

Thus, when $\mathrm{X}=4-\mathrm{MeO}$ and $\mathrm{Y}=3-\mathrm{MeO}$, the min value of DKIE $\left(k_{\mathrm{H}} / k_{\mathrm{D}}=0.55\right)$ is observed (Table 3$)$, indicating that the degree of bond formation is largest and the steric congestion is greatest in the TS. The smallest magnitudes of $\rho_{\mathrm{X}}=-3.67(\mathrm{Y}=3-\mathrm{MeO})$ and $\rho_{\mathrm{Y}}=0.41(\mathrm{X}=4-\mathrm{MeO})$ suggest that the positive and negative charge developments at the nitrogen and phosphorus atom, respectively, are smallest in the TS. This implies that the TS is very tight in which the degree of bond formation is largest while the degree of bond breaking is smallest. When $\mathrm{X}=4-\mathrm{Cl}$ and $\mathrm{Y}=4-\mathrm{MeO}$, on the contrary, the max value of DKIE $\left(k_{\mathrm{H}} / k_{\mathrm{D}}=0.98\right)$ is observed (Table 3), indicating that the degree of bond formation is the smallest and the steric congestion is the smallest in the TS. The largest magnitudes of $\rho_{\mathrm{X}}=-4.43(\mathrm{Y}=4-\mathrm{MeO})$ and $\rho_{\mathrm{Y}}=$ $1.61(\mathrm{X}=4-\mathrm{Cl})$ suggest that the positive and negative charge developments at the nitrogen and phosphorus atom, respectively, are greatest in the TS. This implies that the TS is somewhat looser compared to that when $\mathrm{X}=4-\mathrm{MeO}$ and $\mathrm{Y}$ $=3-\mathrm{MeO}$ in which the degree of bond formation is smallest while the degree of bond breaking is largest. This suggestion is completely contrary to normal expectation: (i) the greater degree of bond formation leads to a greater magnitude of $\rho_{\mathrm{X}}$ value and greater positive charge development at the nucleophilic reaction center; (ii) the greater degree of bond breaking leads to a greater magnitude of $\rho_{\mathrm{Y}}$ value and

Table 3. The DKIEs $\left(k_{\mathrm{H}} / k_{\mathrm{D}}\right), \rho_{\mathrm{X}}$, and $\rho_{\mathrm{Y}}$ for the reactions of $\mathbf{1}$ [bis(Y-aryl) chlorophosphates] with $\mathrm{XC}_{6} \mathrm{H}_{4} \mathrm{NH}_{2}\left(\mathrm{D}_{2}\right)$ in $\mathrm{MeCN}$ at $35.0{ }^{\circ} \mathrm{C}$

\begin{tabular}{cccccc}
\hline $\mathrm{X} \backslash \mathrm{Y}$ & $4-\mathrm{MeO}$ & $4-\mathrm{Me}$ & $\mathrm{H}$ & $3-\mathrm{MeO}$ & $\rho_{\mathrm{Y}}$ \\
\hline $4-\mathrm{MeO}$ & $0.74 \pm 0.01$ & $0.65 \pm 0.01$ & $0.58 \pm 0.01$ & $0.55 \pm 0.01$ & $0.41 \pm 0.01$ \\
$\mathrm{H}$ & $0.86 \pm 0.01$ & $0.83 \pm 0.01$ & $0.77 \pm 0.01$ & $0.73 \pm 0.01$ & $0.96 \pm 0.08$ \\
$4-\mathrm{Cl}$ & $0.98 \pm 0.01$ & $0.96 \pm 0.01$ & $0.95 \pm 0.01$ & $0.94 \pm 0.03$ & $1.61 \pm 0.02$ \\
$-\rho_{\mathrm{X}}$ & $4.43 \pm 0.02$ & $4.21 \pm 0.03$ & $3.93 \pm 0.06$ & $3.67 \pm 0.02$ & \\
\hline
\end{tabular}

Table 4. The DKIEs $\left(k_{\mathrm{H}} / k_{\mathrm{D}}\right), \rho_{\mathrm{X}}$, and $\rho_{\mathrm{Y}}$ for the reactions of 2 [Yaryl phenyl chlorophosphates] with $\mathrm{XC}_{6} \mathrm{H}_{4} \mathrm{NH}_{2}\left(\mathrm{D}_{2}\right)$ in $\mathrm{MeCN}$ at $55.0{ }^{\circ} \mathrm{C}^{a}$

\begin{tabular}{ccccc}
\hline $\mathrm{X} \backslash \mathrm{Y}$ & $4-\mathrm{Me}$ & $\mathrm{H}$ & $4-\mathrm{Cl}$ & $\rho_{\mathrm{Y}}$ \\
\hline $4-\mathrm{MeO}$ & $0.87 \pm 0.03$ & $0.77 \pm 0.05$ & $0.65 \pm 0.02$ & $0.87 \pm 0.01$ \\
$\mathrm{H}$ & $0.85 \pm 0.01$ & $0.75 \pm 0.06$ & $0.64 \pm 0.05$ & $0.54 \pm 0.01$ \\
$4-\mathrm{Cl}$ & $0.81 \pm 0.01$ & $0.71 \pm 0.02$ & $0.61 \pm 0.02$ & $0.22 \pm 0.01$ \\
$-\rho_{\mathrm{X}}$ & $3.55 \pm 0.20$ & $3.74 \pm 0.21$ & $4.09 \pm 0.19$ & \\
\hline
\end{tabular}

${ }^{a}$ All of the values are taken from ref $1 \mathrm{a}$. greater negative charge development at the substrate reaction center.

On the contrary, in $\mathbf{2}$, the results of DKIEs are consistent with normal expectation for the magnitudes of $\rho_{\mathrm{X}}$ and $\rho_{\mathrm{Y}}$ values. When $\mathrm{X}=4-\mathrm{MeO}$ and $\mathrm{Y}=4-\mathrm{Cl}$, the min value of DKIE $\left(k_{\mathrm{H}} / k_{\mathrm{D}}=0.65\right)$ is observed (Table 4$)$, indicating that the degree of bond formation is largest and the steric congestion is greatest in the TS. The largest magnitudes of $\rho_{\mathrm{X}}=-4.09(\mathrm{Y}=4-\mathrm{Cl})$ and $\rho_{\mathrm{Y}}=0.87(\mathrm{X}=4-\mathrm{MeO})$ suggest that the positive and negative charge developments at the nitrogen and phosphorus atom, respectively, are largest in the TS. This implies that the TS is very late in which both the degrees of bond formation and breaking are largest. When $\mathrm{X}=4-\mathrm{Cl}$ and $\mathrm{Y}=4-\mathrm{Me}$, the max value of DKIE $\left(k_{\mathrm{H}} /\right.$ $k_{\mathrm{D}}=0.81$ ) is observed (Table 4), indicating that the degree of bond formation is the smallest and the steric congestion is the smallest in the TS. The smallest magnitudes of $\rho_{\mathrm{X}}=$ $-3.55(\mathrm{Y}=4-\mathrm{Me})$ and $\rho_{\mathrm{Y}}=0.22(\mathrm{X}=4-\mathrm{Cl})$ suggest that the positive and negative charge developments at the nitrogen and phosphorus atom, respectively, are smallest in the TS. This implies that both the degrees of bond formation and breaking are smallest.

In this respect, DKIEs have provided a useful means to determine the TS structures in nucleophilic substitution reactions, and how the reactants, especially through changes in substituents, alter the TS structures. Incorporation of deuterium in the nucleophile has an advantage in that the $\alpha$ DKIEs reflect only the degree of bond formation, especially for the secondary inverse DKIEs. Thus, the greater the extent of bond formation, the greater the steric congestion, and the smaller the $k_{\mathrm{H}} / k_{\mathrm{D}}$ value becomes. These results indicate that the DKIEs are one of the strong tools to substantiate the TS structure, and that the determination of TS structure with $\rho_{\mathrm{X}}$ and $\rho_{\mathrm{X}}$ values is not sometimes adequate.

The second-order rate constants $\left(k_{\mathrm{H}}\right)$ of the reactions of five chlorophosphates (when $\mathrm{Y}=\mathrm{H}$ ) with unsubstitued aniline $\left(\mathrm{C}_{6} \mathrm{H}_{5} \mathrm{NH}_{2}\right)$ at $55.0{ }^{\circ} \mathrm{C}$, natural bond order $(\mathrm{NBO})$ charges at the $\mathrm{P}$ reaction center in the gas phase [B3LYP/6$311+\mathrm{G}(\mathrm{d}, \mathrm{p})$ level of theory], ${ }^{13}$ Brönsted and Hammett coefficients $\left(\beta_{\mathrm{X}}\right.$ and $\left.\rho_{\mathrm{Y}}\right), \mathrm{CICs}\left(\rho_{\mathrm{XY}}\right)$, and DKIEs $\left(k_{\mathrm{H}} / k_{\mathrm{D}}\right)$ of the reactions of five chlorophosphates with $\mathrm{XC}_{6} \mathrm{H}_{4} \mathrm{NH}_{2}\left(\mathrm{D}_{2}\right)$ in $\mathrm{MeCN}$ are summarized in Table 5. Solely considering the magnitudes of the positive charges at the reaction center $\mathrm{P}$ atom, the sequence of the anilinolysis rate should be $\mathbf{4}>\mathbf{3}>$ $\mathbf{2}>\mathbf{5}$ (note $\mathbf{1}=\mathbf{2}$ when $\mathrm{Y}=\mathrm{H}$ ). However, the observed sequence of the rate, $\mathbf{5}>\mathbf{4}>\mathbf{3}>\mathbf{2}$, is not consistent with expectations for the electronic influence of the two ligands. It is evident that the magnitude of the positive charge at the reaction center $\mathrm{P}$ atom does not play any role to determine the anilinolysis rate of the chlorophosphate systems. The second-order rate constants for the reactions of four chlorophosphates $\left(\mathbf{2}, \mathbf{3}, \mathbf{4}\right.$, and 5) with $\mathrm{C}_{6} \mathrm{H}_{5} \mathrm{NH}_{2}$ in $\mathrm{MeCN}$ at 55.0 ${ }^{\circ} \mathrm{C}$ give the relative rate ratio of $4.8(5)^{41}: 3.2(4)^{4 \mathrm{i}}: 2.2(3)^{4 \mathrm{~d}}$ : 1(2). ${ }^{15}$ The sequence of the anilinolysis rates of the chlorophosphates, $\mathbf{5}>\mathbf{4}>\mathbf{3}>\mathbf{2}$, is inversely proportional to the size of the two ligands; $\mathrm{PhO}, \mathrm{PhO}$ (2) $>\mathrm{PhO}$,EtO (3) $>$ 
Table 5. Summary of the second-order rate constants $\left(k_{\mathrm{H}} \times 10^{3} / \mathrm{M}^{-1} \mathrm{~s}^{-1}\right)$ with $\mathrm{C}_{6} \mathrm{H}_{5} \mathrm{NH}_{2}$ at $55.0{ }^{\circ} \mathrm{C}$, NBO charges at the $\mathrm{P}$ reaction center, Brönsted and Hammett coefficients $\left(\beta_{\mathrm{X}}\right.$ and $\left.\rho_{\mathrm{Y}}\right)$, CICs $\left(\rho_{\mathrm{XY}}\right)$, and DKIEs $\left(k_{\mathrm{H}} / k_{\mathrm{D}}\right)$ of the reactions of $\mathbf{1 , 2}, \mathbf{3}, \mathbf{4}$, and $\mathbf{5}$ with $\mathrm{XC}_{6} \mathrm{H}_{4} \mathrm{NH}_{2}\left(\mathrm{D}_{2}\right)$ in $\mathrm{MeCN}$

\begin{tabular}{lccccccc}
\hline \multicolumn{1}{c}{ Substrate } & $k_{\mathrm{H}} \times 10^{3}$ & charge at $\mathrm{P}$ & $\beta_{\mathrm{X}}$ & $\rho_{\mathrm{Y}}$ & $\rho_{\mathrm{XY}}$ & $k_{\mathrm{H}} / k_{\mathrm{D}}$ & ref \\
\hline $\mathbf{1} ;\left(\mathrm{YC}_{6} \mathrm{H}_{4} \mathrm{O}\right)_{2} \mathrm{P}(=\mathrm{O}) \mathrm{Cl}$ & $0.891^{a}$ & $2.230^{a}$ & $1.29-1.56^{b}$ & $0.41-1.61^{b}$ & $+1.91^{b}$ & $0.55-0.98^{b}$ & this work \\
$\mathbf{2} ;\left(\mathrm{YC} \mathrm{H}_{4} \mathrm{O}\right)(\mathrm{PhO}) \mathrm{P}(=\mathrm{O}) \mathrm{Cl}$ & $0.891^{a}$ & $2.230^{a}$ & $1.24-1.68^{c}$ & $0.22-0.87^{c}$ & $-1.31^{c}$ & $0.61-0.87^{c}$ & $1 \mathrm{a}$ \\
$\mathbf{3} ;\left(\mathrm{YC} \mathrm{H}_{4} \mathrm{O}\right)(\mathrm{EtO}) \mathrm{P}(=\mathrm{O}) \mathrm{Cl}$ & $2.00^{a}$ & $2.233^{a}$ & $1.09-1.20^{c}$ & $0.41-0.90^{c}$ & $-0.60^{c}$ & $1.07-1.28^{c}$ & $1 \mathrm{f}$ \\
$\mathbf{4} ;(\mathrm{EtO})_{2} \mathrm{P}(=\mathrm{O}) \mathrm{Cl}$ & 2.82 & 2.236 & $1.06^{c}$ & - & - & $0.71-0.92^{c}$ & $1 \mathrm{~g}$ \\
$\left.\mathbf{5} ;(\mathrm{MeO})_{2} \mathrm{P}=\mathrm{O}\right) \mathrm{Cl}$ & 4.28 & 2.226 & $0.962^{c}$ & - & - & $0.80-0.98^{c}$ & $1 \mathrm{~g}$ \\
\hline
\end{tabular}

${ }^{a}$ The values of $\mathrm{Y}=\mathrm{H}$ at $55.0^{\circ} \mathrm{C} .{ }^{b}$ The values at $35.0^{\circ} \mathrm{C} .{ }^{c}$ The values at $55.0^{\circ} \mathrm{C}$.

EtO,EtO (4) $>\mathrm{MeO}, \mathrm{MeO}$ (5). The greater the size of the two ligands, the anilinolysis rate becomes slower. This means that the steric effects of the two ligands are the predominant factor to determine the reactivity of the anilinolysis of chlorophosphates.

The values of $\rho_{\mathrm{Y}}$ of $\mathbf{1}$ are almost two times greater than those of $\mathbf{2}$ since the values of $\rho_{\mathrm{Y}}$ of $\mathbf{1}$ are calculated not with $2 \times \sigma_{\mathrm{Y}}$ but with $1 \times \sigma_{\mathrm{Y}}$, i.e., the contribution of one $\mathrm{Y}$ to $\rho_{\mathrm{Y}}$ is the same as in 2. It is worthy of note that the magnitudes of the selectivity parameters $\left(\beta_{\mathrm{X}}\right.$ and $\left.\rho_{\mathrm{Y}}\right)$ of $\mathbf{1}$ and $\mathbf{2}$ are similar $\left[\beta_{\mathrm{X}}=1.29-1.56(\mathbf{1})\right.$ and $1.24-1.68(2) ; \rho_{\mathrm{Y}}=(0.41-1.61) / 2=$ $0.21-0.81(\mathbf{1})$ and $0.22-0.87$ (2) as mentioned already] despite the different reaction mechanism of a concerted (2) and stepwise with a rate-limiting bond breaking step (1). This implies that the clarification of the reaction mechanism with the values of $\rho_{\mathrm{X}}, \beta_{\mathrm{X}}$, and/or $\rho_{\mathrm{Y}}$ is sometimes dangerous, and the CICs are one of strong tools to substantiate the mechanism. The anilinolyses of the chloro(or thiochloro)phosphate derivatives normally proceed through a normal $\mathrm{S}_{\mathrm{N}} 2$ concerted mechanism because of a good leaving group mobility of $\mathrm{Cl}$. Until now, only the reactions of $O$-aryl methyl phosphonochloridothioate $\left[\mathrm{Me}\left(\mathrm{YC}_{6} \mathrm{H}_{4} \mathrm{O}\right) \mathrm{P}(=\mathrm{S}) \mathrm{Cl}\right]$ with the weakly basic anilines in $\mathrm{MeCN}$ at $55.0^{\circ} \mathrm{C}$ yielded a positive value of $\rho_{\mathrm{XY}}=+0.77,{ }^{\mathrm{lk}}$ and now the present work yields a positive value of $\rho_{\mathrm{XY}}=+1.91$. Considering the two Ys in the two phenyl rings, the magnitude of $\rho_{\mathrm{XY}}$ per one $\mathrm{Y}$ would be $1.91 / 2=+0.96$.

The DKIEs of four chlorophsphates $\left[\mathbf{1}\left(k_{\mathrm{H}} / k_{\mathrm{D}}=0.55\right.\right.$ $0.98), 2\left(k_{\mathrm{H}} / k_{\mathrm{D}}=0.61-0.87\right), 4\left(k_{\mathrm{H}} / k_{\mathrm{D}}=0.71-0.92\right)$, and $\mathbf{5}\left(k_{\mathrm{H}} /\right.$ $\left.\left.k_{\mathrm{D}}=0.80-0.98\right)\right]$ are secondary inverse. However, in $\mathbf{3}$, the subtle combination of small ethoxy and large phenoxy ligand gave primary normal DKIEs $\left(k_{\mathrm{H}} / k_{\mathrm{D}}=1.07-1.28\right)$. The authors proposed that the anilinolyses of $\mathbf{2}, \mathbf{4}$, and 5 proceed through a concerted mechanism involving a predominant backside attack TSb on the basis of the negative sign of $\rho_{\mathrm{XY}}$ and the secondary inverse DKIEs, whereas the anilinolysis of $\mathbf{3}$ proceeds through a concerted mechanism involving a predominant frontside attack with a hydrogen-bonded, fourcenter-type TSf on the basis of the negative sign of $\rho_{\mathrm{XY}}$ and the considerably large primary normal DKIEs. In the present work, the authors propose a stepwise mechanism with a ratelimiting leaving group expulsion from the intermediate involving a predominant backside attack TSb on the basis of the positive sign of $\rho_{\mathrm{XY}}(=+1.91)$ and the secondary inverse DKIEs $\left(k_{\mathrm{H}} / k_{\mathrm{D}}=0.55-0.98\right)$.

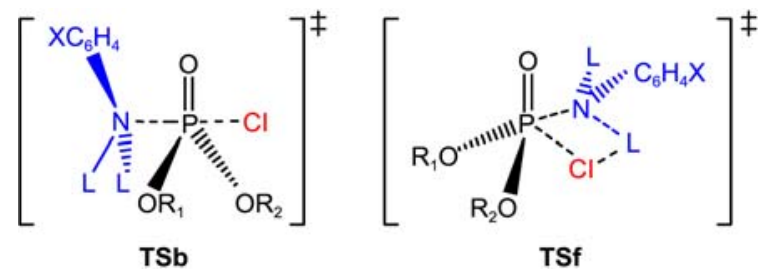

\section{Experimental Section}

Materials. Bis(phenyl) chlorophosphate (GR grade) and $\mathrm{MeCN}$ (HPLC-grade; water content is less than $0.005 \%$ ) were used for kinetic studies without further purification. Anilines were redistilled or recrystallized before use. Deuterated anilines were prepared by heating anilines, deuterium oxide ( 99.9 atom \% D), and one drop of $\mathrm{HCl}$ catalyst at 90 ${ }^{\circ} \mathrm{C}$ for 72 hours, and after numerous attempts, anilines were deuterated more than $98 \%$, as confirmed by ${ }^{1} \mathrm{H}$ NMR.

Kinetic Measurement. Conductometric rate measurements were carried out using self-made computer-interfaced automatic A/D converter conductivity bridges. The pseudofirst-order rate constants $\left(k_{\text {obsd }}\right)$ were determined using large excess of nucleophiles where $[\mathrm{X}$-anilines $]=0.10-0.30 \mathrm{M}$ and [Substrate] $=3.00 \times 10^{-3} \mathrm{M}$. Rates were measured as previously described. ${ }^{1}$ The values of pseudo-first-order rate constants were average of at least three runs that were reproducible within $\pm 3 \%$.

Synthesis of Substrates. The substrates, bis(Y-aryl) chlorophosphates $(\mathrm{Y}=4-\mathrm{MeO}, 4-\mathrm{Me}$, and 3-MeO), were synthesized by reacting phosphorus oxychloride with Y-phenol in the presence of triethylamine in methylene chloride at $-10{ }^{\circ} \mathrm{C} .{ }^{14}$ Triethylammonium chloride was separated by filtration. The remaining mixture was treated with water and diethyl ether for work up. Organic layer of diethyl ether was dried over anhydrous $\mathrm{MgSO}_{4}$ for 6-8 hr. The product mixture was separated through column chromatography (silica gel, ethyl acetate $/ n$-hexane) and dried under reduced pressure. The substrates were characterized by the spectral analysis, TLC, ${ }^{1} \mathrm{H}-\mathrm{NMR},{ }^{13} \mathrm{C}-\mathrm{NMR},{ }^{31} \mathrm{P}-\mathrm{NMR}, \mathrm{GC}-\mathrm{MS}$ and Element Analysis (EA), as follows:

Bis(4-methoxyphenyl) Chlorophosphate $\left[\left(4-\mathrm{CH}_{3} \mathrm{O}-\right.\right.$ $\left.\left.\mathbf{C}_{6} \mathbf{H}_{4} \mathbf{O}\right)_{2} \mathbf{P}(=\mathbf{O}) \mathbf{C l}\right]$ : Light brown oily liquid; ${ }^{1} \mathrm{H}-\mathrm{NMR}(400$ $\mathrm{MHz}, \mathrm{CDCl}_{3} \& \mathrm{TMS}$ ) $\delta$ 3.80-3.81 (aliphatic, $6 \mathrm{H}, \mathrm{m}$ ), 6.886.90 (aromatic, $4 \mathrm{H}, \mathrm{m}$ ); 7.20-7.22 (aromatic, $4 \mathrm{H}, \mathrm{m}$ ); ${ }^{13} \mathrm{C}-$ NMR (100 MHz, $\mathrm{CDCl}_{3} \&$ TMS) $\delta 55.65$ (aliphatic, 2C, s), 
114.89-157.68 (aromatic, 12C, m); ${ }^{31} \mathrm{P}-\mathrm{NMR}(162 \mathrm{MHz}$, $\left.\mathrm{CDCl}_{3} \& \mathrm{TMS}\right) \delta 1.66(\mathrm{PO}, 1 \mathrm{P}, \mathrm{s}) ; \mathrm{GC}-\mathrm{MS}(\mathrm{EI}, \mathrm{m} / \mathrm{z}) 328$ $\left(\mathrm{M}^{+}\right)$.

Bis(4-methylphenyl) Chlorophosphate $\left[\left(4-\mathrm{CH}_{3}-\mathrm{C}_{6} \mathrm{H}_{4} \mathrm{O}\right)_{2}-\right.$ $\mathbf{P}(=\mathbf{O}) \mathbf{C l}$ ): Oily colorless liquid; ${ }^{1} \mathrm{H}-\mathrm{NMR}\left(400 \mathrm{MHz}, \mathrm{CDCl}_{3}\right.$ \& TMS) $\delta$ 2.26-2.40 (aliphatic, 6H, m), 7.01-7.23 (aromatic, $8 \mathrm{H}, \mathrm{m}) ;{ }^{13} \mathrm{C}-\mathrm{NMR}\left(100 \mathrm{MHz}, \mathrm{CDCl}_{3} \& \mathrm{TMS}\right) \delta 20.75$ (aliphatic, 2C, d, $J=7.0 \mathrm{~Hz}$ ), 119.84-148.26 (aromatic, 12C, $\mathrm{m}) ;{ }^{31} \mathrm{P}-\mathrm{NMR}$ (162 MHz, $\left.\mathrm{CDCl}_{3} \& \mathrm{TMS}\right) \delta-3.44$ (PO, 1P, s); GC-MS (EI, $m / z) 296\left(\mathrm{M}^{+}\right)$.

Bis(3-methoxyphenyl) Chlorophosphate [(3-CH $\mathrm{H}_{3} \mathrm{O}$ $\left.\mathbf{C}_{6} \mathbf{H}_{4} \mathbf{O}\right)_{2} \mathbf{P}(=\mathbf{O}) \mathbf{C l}$ : Oily colorless liquid; ${ }^{1} \mathrm{H}-\mathrm{NMR}$ (400 $\mathrm{MHz}, \mathrm{CDCl}_{3} \& \mathrm{TMS}$ ) $\delta 3.81$ (aliphatic, $6 \mathrm{H}, \mathrm{m}$ ), 6.81-6.92 (aromatic, 6H, m); 7.26-7.31 (aromatic, 2H, m); ${ }^{13} \mathrm{C}-\mathrm{NMR}$ (100 MHz, $\left.\mathrm{CDCl}_{3} \& \mathrm{TMS}\right) \delta 55.55$ (aliphatic, 2C, s), 101.48-160.83 (aromatic, 12C, m); ${ }^{31} \mathrm{P}-\mathrm{NMR}$ (162 MHz, $\left.\mathrm{CDCl}_{3} \& \mathrm{TMS}\right) \delta-0.068(\mathrm{P}=\mathrm{O}, 1 \mathrm{P}, \mathrm{s})$; GC-MS (EI, $\left.m / z\right) 328$ $\left(\mathrm{M}^{+}\right)$and Anal. Calcd for $\mathrm{C}_{14} \mathrm{H}_{14} \mathrm{ClO}_{5} \mathrm{P}$ : C 51.16, H 4.29; Found: C 51.26, H 4.15.

Product Analysis. Bis(phenyl) chlorophosphate was reacted with excess amount of 4-methoxyaniline for more than 15 half-lives in $\mathrm{MeCN}$ at $35.0{ }^{\circ} \mathrm{C}$. The product was isolated through column chromatography ( $50 \%$ ethyl acetate/ $n$-hexane) after treatment with ether and dilute $\mathrm{HCl}$, then dried under reduced pressure. The analytical data are summarized as follows:

$\left(\mathrm{C}_{6} \mathrm{H}_{5} \mathrm{O}\right)_{2} \mathbf{P}(=\mathrm{O})\left(\mathrm{NHC}_{6} \mathrm{H}_{\mathbf{4}}-\mathbf{4}-\mathrm{OCH}_{3}\right)$ : White solid crystal, mp 139.0-140.0 ${ }^{\circ} \mathrm{C} ;{ }^{1} \mathrm{H}-\mathrm{NMR}$ (400 MHz, $\left.\mathrm{CDCl}_{3} \& \mathrm{TMS}\right) \delta$ 3.79 (aliphatic, 3H, s), 5.73 (aliphatic, 1H, s), 6.83-6.86 (aromatic, 2H, m), 7.04-7.07 (aromatic, 2H, m), 7.13-7.20 (aromatic, 6H, m), 7.21-7.31 (aromatic, 4H, m); ${ }^{13} \mathrm{C}-\mathrm{NMR}$ $\left(100 \mathrm{MHz}, \mathrm{CDCl}_{3} \& \mathrm{TMS}\right) \delta 55.53$ (aliphatic, 1C, s), 114.67-150.37 (aromatic, 18C, s); ${ }^{31} \mathrm{P}-\mathrm{NMR}$ (162 MHz, $\left.\mathrm{CDCl}_{3} \& \mathrm{TMS}\right) \delta-1.43(\mathrm{P}=\mathrm{O}, 1 \mathrm{P}, \mathrm{s})$; GC-MS (EI, $\left.m / z\right) 355$ $\left(\mathrm{M}^{+}\right)$and Anal. Calcd for $\mathrm{C}_{19} \mathrm{H}_{18} \mathrm{NO}_{4} \mathrm{P}: \mathrm{C}$ 64.22, $\mathrm{H} 5.11, \mathrm{~N}$ 3.94; Found: C 64.06, H 5.29, N 3.93.

Acknowledgments. This work was supported by the Brain Korea 21 Program from National Research Foundation of Korea.

\section{References and Notes}

1. (a) Guha, A. K.; Lee, H. W.; Lee, I. J. Chem. Soc., Perkin Trans. 2 1999, 765. (b) Lee, H. W.; Guha, A. K.; Lee, I. Int. J. Chem. Kinet. 2002, 34, 632. (c) Hoque, M. E. U.; Dey, S.; Guha, A. K.; Kim, C. K.; Lee, B. S.; Lee, H. W. J. Org. Chem. 2007, 72, 5493. (d) Hoque, M. E. U.; Lee, H. W. Bull. Korean Chem. Soc. 2007, 28, 936. (e) Dey, N. K.; Han, I. S.; Lee, H. W. Bull. Korean Chem. Soc. 2007, 28, 2003. (f) Hoque, M. E. U.; Dey, N. K.; Kim, C. K.; Lee, B. S.; Lee, H. W. Org. Biomol. Chem. 2007, 5, 3944. (g) Dey, N. K.; Hoque, M. E. U.; Kim, C. K.; Lee, B. S.; Lee, H. W. J. Phys. Org. Chem. 2008, 21, 544. (h) Lumbiny, B. J.; Lee, H. W. Bull. Korean Chem. Soc. 2008, 29, 2065. (i) Dey, N. K.; Hoque, M. E. U.; Kim, C. K.; Lee, B. S.; Lee, H. W. J. Phys. Org. Chem.
2009, 22, 425. (j) Dey, N. K.; Kim, C. K.; Lee, H. W. Bull. Korean Chem. Soc. 2009, 30, 975. (k) Hoque, M. E. U.; Guha, A. K.; Kim, C. K.; Lee, B. S.; Lee, H. W. Org. Biomol. Chem. 2009, 7, 2919. (1) Dey, N. K.; Lee, H. W. Bull. Korean Chem. Soc. 2010, 31, 1403. (m) Dey, N. K.; Kim, C. K.; Lee, H. W. Org. Biomol. Chem. 2011, 9, 717.

2. (a) Guha, A. K.; Lee, H. W.; Lee, I. J. Org. Chem. 2000, 65, 12. (b) Lee, H. W.; Guha, A. K.; Kim, C. K.; Lee, I. J. Org. Chem. 2002, 67, 2215. (c) Adhikary, K. K.; Lee, H. W.; Lee, I. Bull. Korean Chem. Soc. 2003, 24, 1135. (d) Hoque, M. E. U.; Dey, N. K.; Guha, A. K.; Kim, C. K.; Lee, B. S.; Lee, H. W. Bull. Korean Chem. Soc. 2007, 28, 1797. (e) Adhikary, K. K.; Lumbiny, B. J.; Kim, C. K.; Lee, H. W. Bull. Korean Chem. Soc. 2008, 29, 851. (f) Lumbiny, B. J.; Adhikary, K. K.; Lee, B. S.; Lee, H. W. Bull. Korean Chem. Soc. 2008, 29, 1769. (g) Dey, N. K.; Hoque, M. E. U.; Kim, C. K.; Lee, H. W. J. Phys. Org. Chem. 2010, 23, 1022. (h) Dey, N. K.; Adhikary, K. K.; Kim, C. K.; Lee, H. W. Bull. Korean Chem. Soc. 2010, 31, 3856. (i) Dey, N. K.; Kim, C. K.; Lee, H. W. Bull. Korean Chem. Soc. 2011, 32, 709. (j) Hoque, M. E. U.; Dey, S.; Kim, C. K.; Lee, H. W. Bull. Korean Chem. Soc. 2011, 32, 1138. (k) Guha, A. K.; Hoque, M. E. U.; Lee, H. W. Bull. Korean Chem. Soc. 2011, 32, 1375. (1) Guha, A. K.; Kim, C. K.; Lee, H. W. J. Phys. Org. Chem. 2011, 24, 474.

3. Adhikary, K. K.; Lee, H. W. Bull. Korean Chem. Soc. 2011, 32, 1625.

4. (a) Lee, I.; Kim, C. K.; Li, H. G.; Sohn, C. K.; Kim, C. K.; Lee, H. W.; Lee, B. S. J. Am. Chem. Soc. 2000, 122, 11162. (b) Han, I. S.; Kim, C. K.; Lee, H. W. Bull. Korean Chem. Soc. 2011, 32, 889.

5. Hansch, C.; Leo, A.; Taft, R. W. Chem. Rev. 1991, 91, 165.

6. Streitwieser, A., Jr.; Heathcock, C. H.; Kosower, E. M. Introduction to Organic Chemistry, 4th ed.; Macmillan: New York, 1992; p 735.

7. (a) Lee, I. Chem. Soc. Rev. 1990, 19, 317. (b) Lee, I. Adv. Phys. Org. Chem. 1992, 27, 57. (c) Lee, I.; Lee, H. W. Collect. Czech. Chem. Commun. 1999, 64, 1529.

8. The $\Delta \mathrm{p} K_{\mathrm{a}}=\mathrm{p} K_{\mathrm{a}}(\mathrm{MeCN})-\mathrm{p} K_{\mathrm{a}}\left(\mathrm{H}_{2} \mathrm{O}\right)$ values for structurally similar amines are nearly constant, so determination of $\beta_{\mathrm{X}}$ by plotting log $k_{2}(\mathrm{MeCN})$ against $\mathrm{p} K_{\mathrm{a}}\left(\mathrm{H}_{2} \mathrm{O}\right)$ is probably justified. [(a) Ritchie, C. D. Solute-Solvent Interactions; Coetzee, J. F., Ritchie, C. D., Ed.; Marcel Dekker: New York, 1969; Ch. 4. (b) Coetzee, J. F. Prog. Phys. Org. Chem. 1967, 4, 54. (c) Spillane, W. J.; Hogan, G.; McGrath, P.; King, J.; Brack, C. J. Chem. Soc., Perkin Trans. 2 1996, 2099. (d) Oh, H. K.; Woo, S. Y.; Shin, C. H.; Park, Y. S.; Lee, I. J. Org. Chem. 1997, 62, 5780.]

9. Wold, S.; Sjöström, M. Correlation Analysis in Chemistry; Chapman, N. B., Shorter, J., Eds.; Plenum: New York, 1978; Chapter 4.

10. The values of $\sigma_{\mathrm{X}}$ and $\sigma_{\mathrm{Y}}$ are normally less than unity, and the value of $\sigma_{\mathrm{X}}^{2}$ or $\sigma_{\mathrm{Y}}^{2}$ becomes much smaller than unity. Thus, $\rho_{\mathrm{YY}} \sigma_{\mathrm{Y}} \sigma_{\mathrm{Y}}=0.02 \sigma_{\mathrm{Y}}^{2}$ is almost equal to null $(\approx 0)$.

11. (a) Lee, I.; Koh, H. J.; Lee, B. S.; Lee, H. W. J. Chem. Soc., Chem. Commun. 1990, 335. (b) Poirier, R. A.; Youliang, W.; Westaway, K. C. J. Am. Chem. Soc. 1994, 116, 2526. (c) Lee, I. Chem. Soc. Rev. 1995, 24, 223. (d) Marlier, J. F. Acc. Chem. Res. 2001, 34, 283. (e) Westaway, K. C. Adv. Phys. Org. Chem. 2006, 41, 217. (f) Villano, S. M.; Kato, S.; Bierbaum, V. M. J. Am. Chem. Soc. 2006, 128, 736. (g) Gronert, S.; Fajin, A. E.; Wong, L. J. Am. Chem. Soc. 2007, 129, 5330.

12. Crumpler, T. B.; Yoh, J. H. Chemical Computations and Errors; John Wiley: New York, 1940; 178.

13. Hehre, W. J.; Random, L.; Schleyer, P. V. R.; Pople, J. A. Ab Initio Molecular Orbital Theory; Wiley: New York, 1986; Chapter 4.

14. Wadsworth, W. S., Jr.; Wilde, R. L. J. Org. Chem. 1976, 41, 2635. 


\section{Kinetics and Mechanism of the Anilinolysis of Bis(aryl)}

\section{Chlorophosphates in Acetonitrile}

Hasi Rani Barai and Hai Whang Lee*

Department of Chemistry, Inha University, Incheon 402-751, Korea. *E-mail: hwlee@inha.ac.kr Received April 19, 2011, Accepted April 22, 2011

\section{Substrate: Bis (4-methoxyphenyl) chlorophosphate}

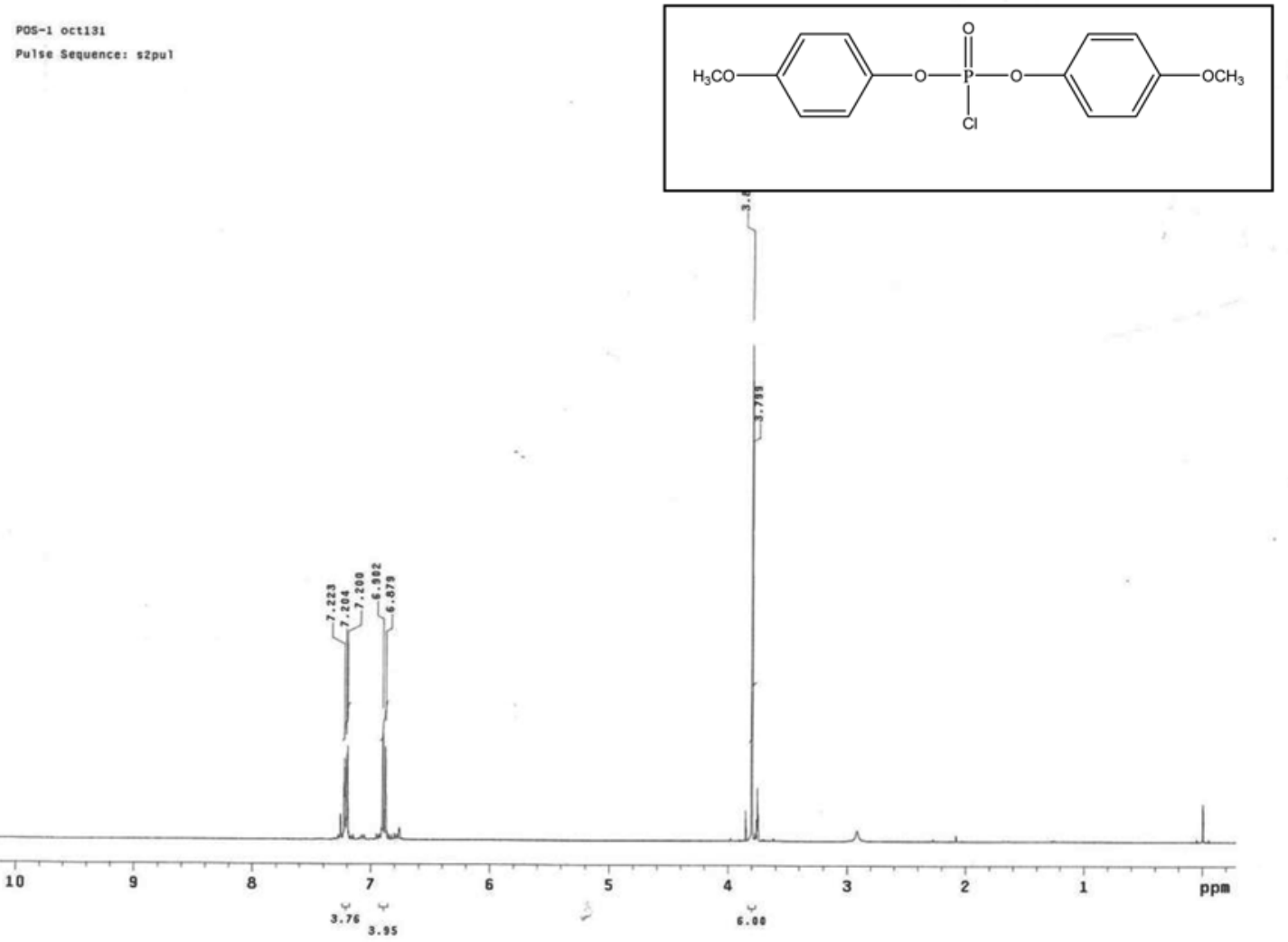

Figure S1. The ${ }^{1}$ H-NMR spectrum of bis(4-methoxyphenyl) chlorophosphate. 


\section{Substrate: Bis (4-methoxyphenyl) chlorophosphate}

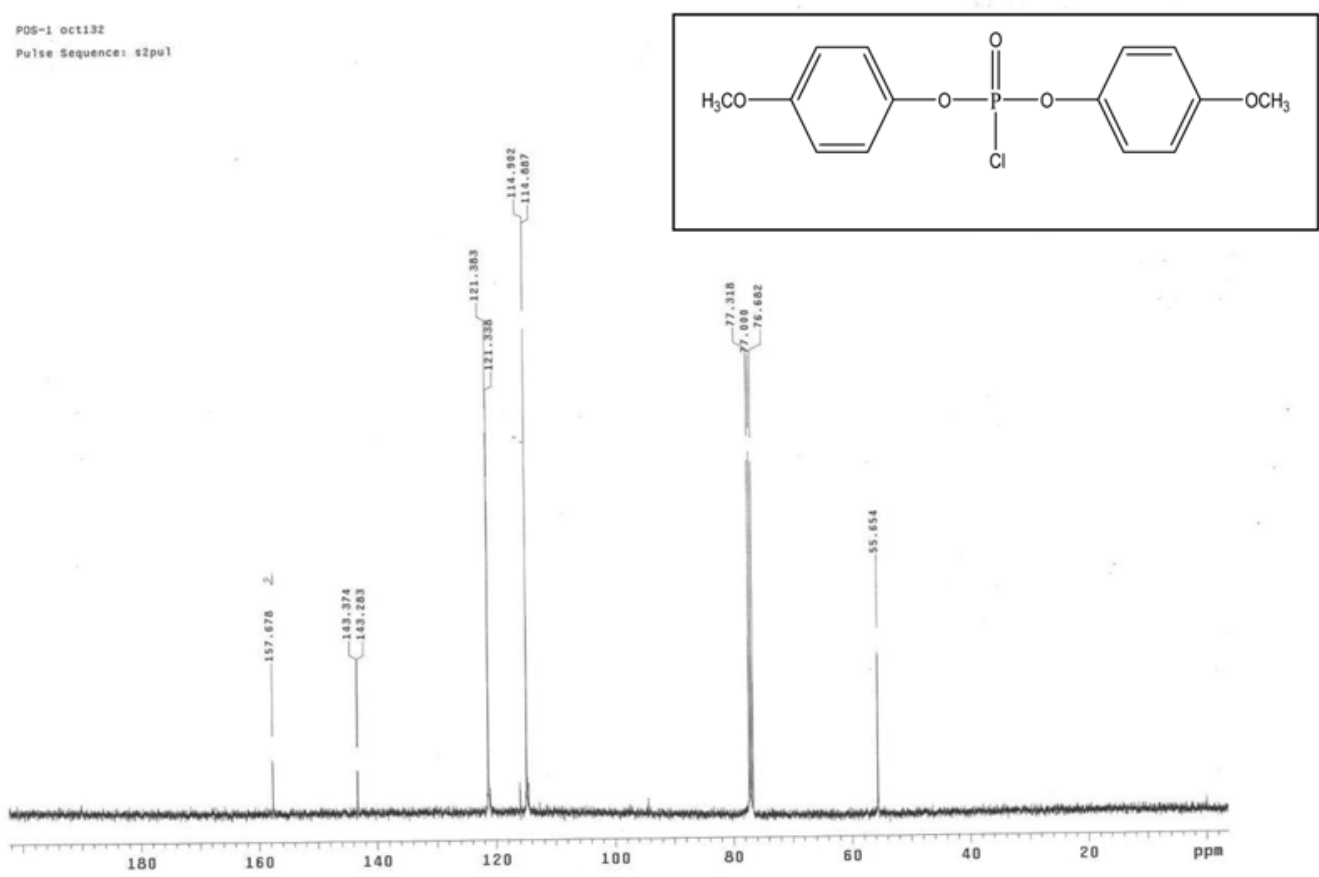

Figure S2. The ${ }^{13} \mathrm{C}$ - NMR spectrum of bis(4-methoxyphenyl) chlorophosphate.

\section{Substrate: Bis (4-methoxyphenyl) chlorophosphate}
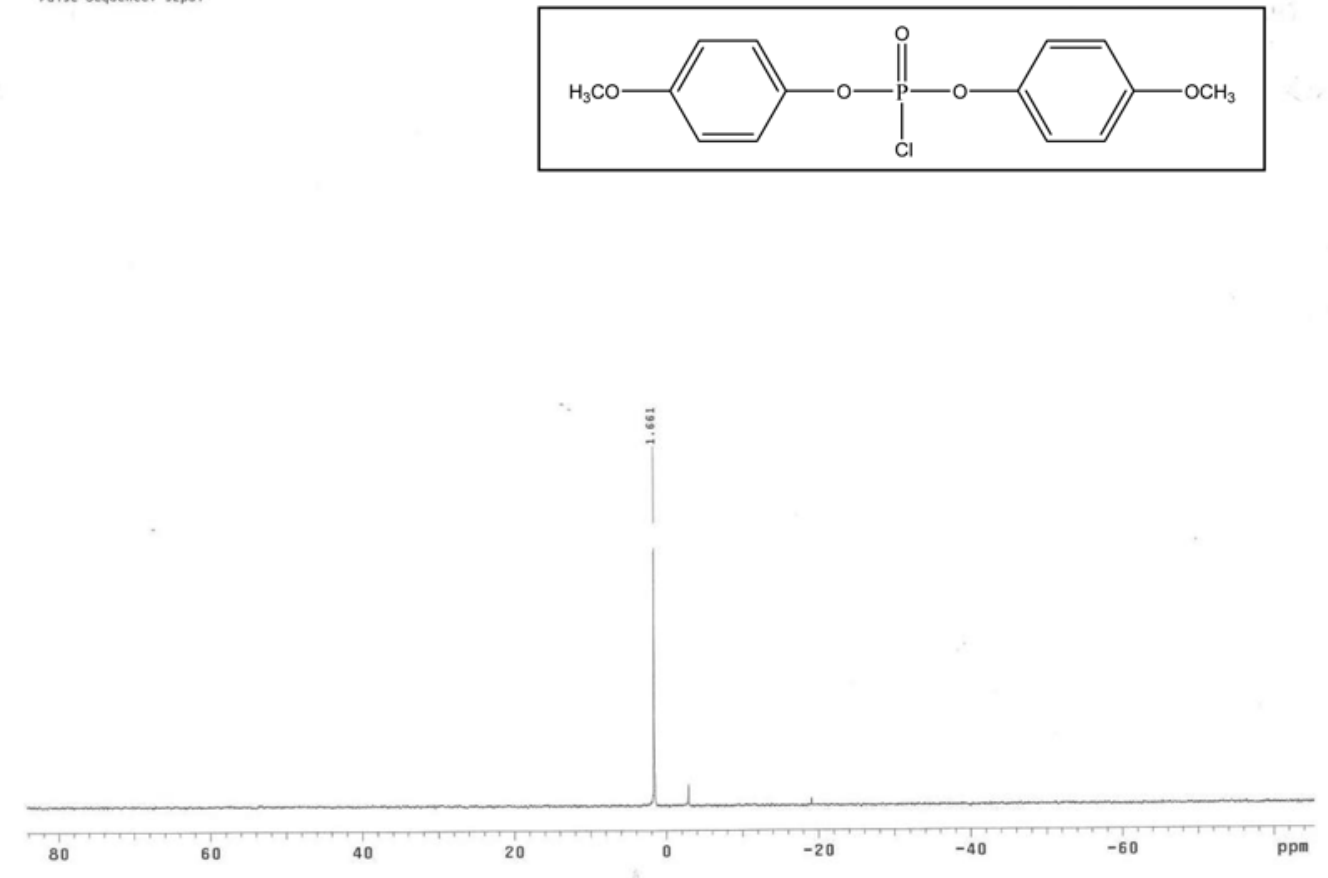

Figure S3. The 31P-NMR spectrum of bis(4-methoxyphenyl) chlorophosphate. 


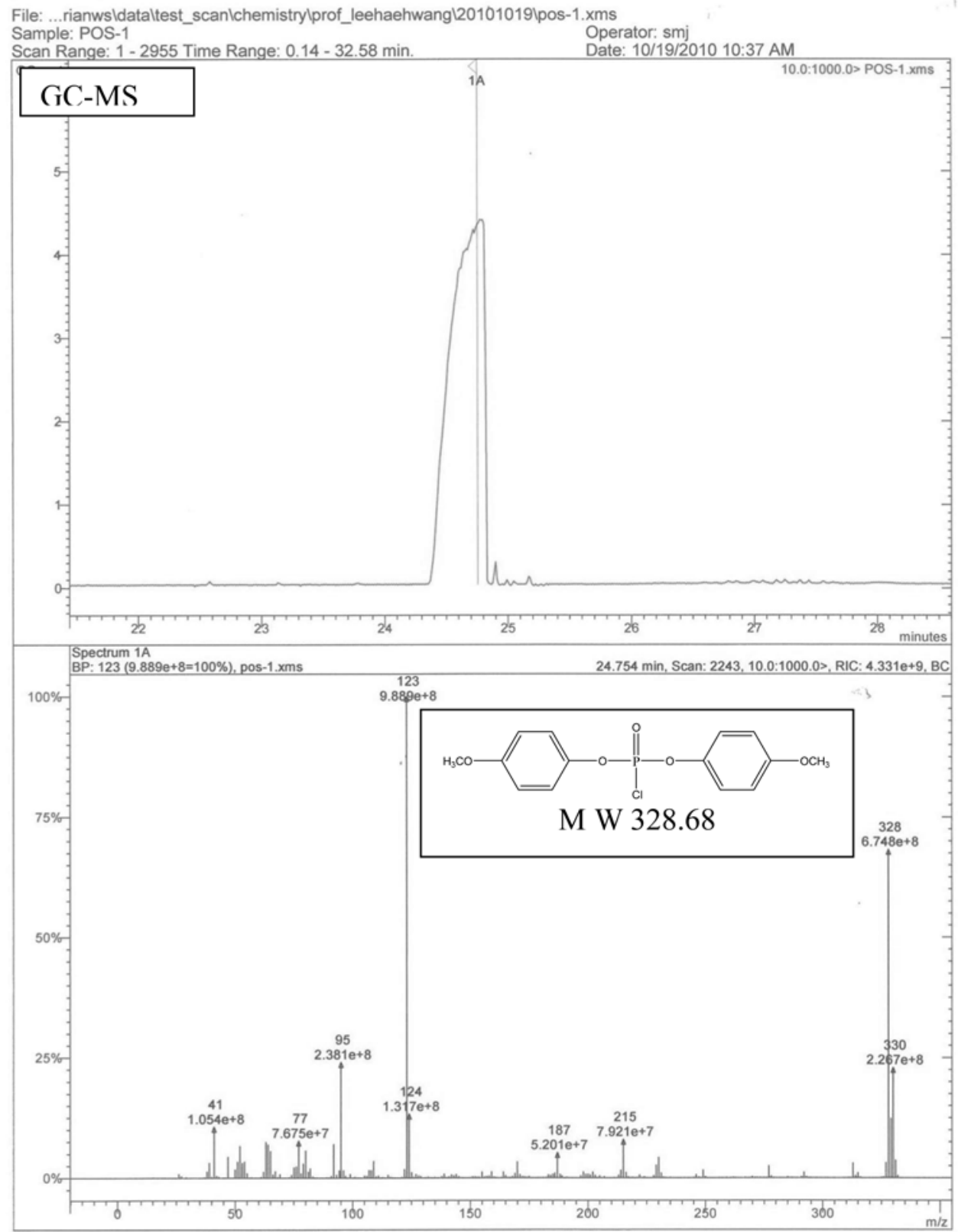

Figure S4. The GC-MS spectrum of bis(4-methoxyphenyl) chlorophosphate. 


\section{Substrate: Bis (4-methylphenyl) chlorophosphate}

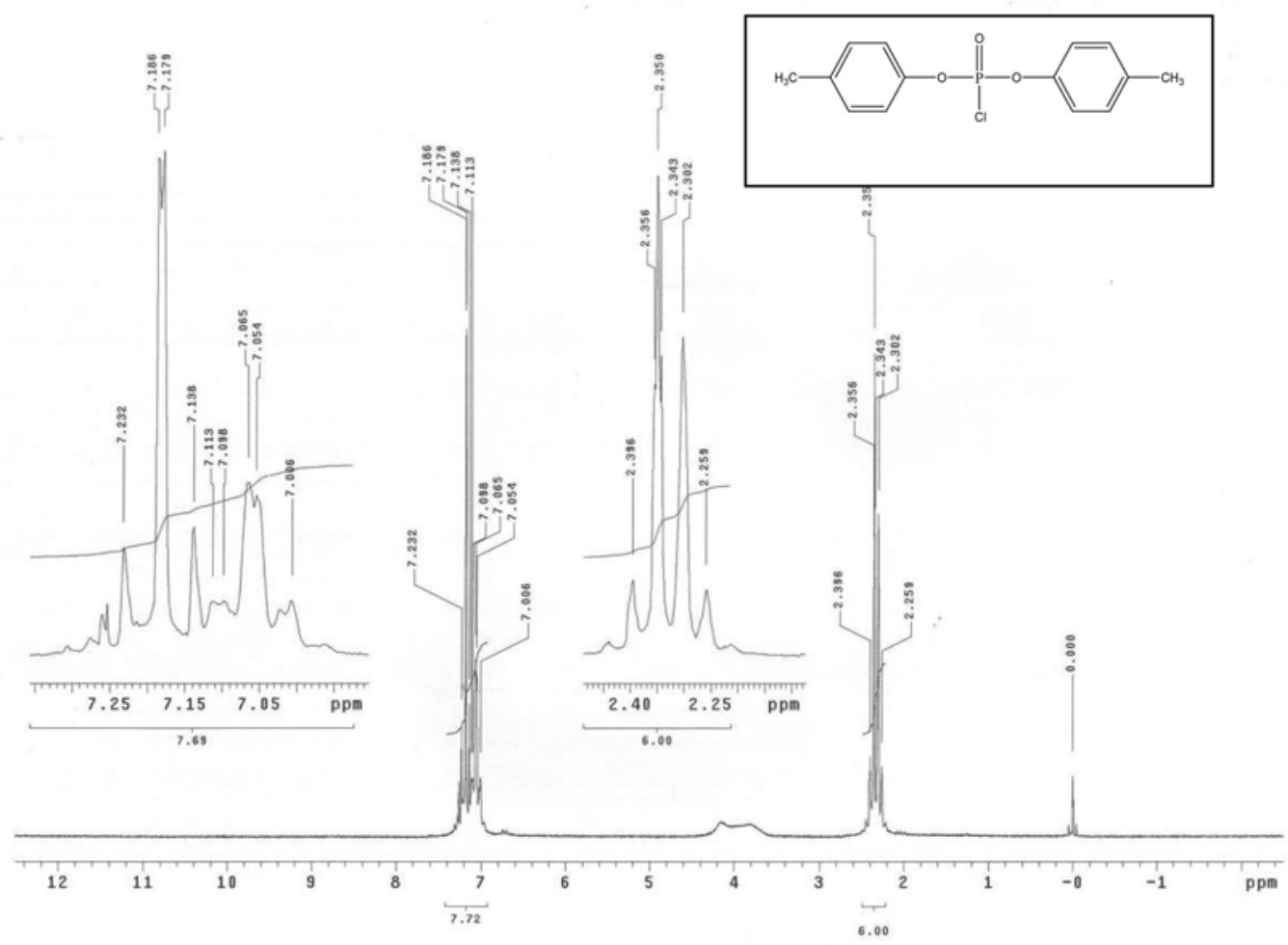

Figure S5. The ${ }^{1} \mathrm{H}-\mathrm{NMR}$ spectrum of bis(4-methylphenyl) chlorophosphate.

\section{Substrate: Bis (4-methylphenyl) chlorophosphate}

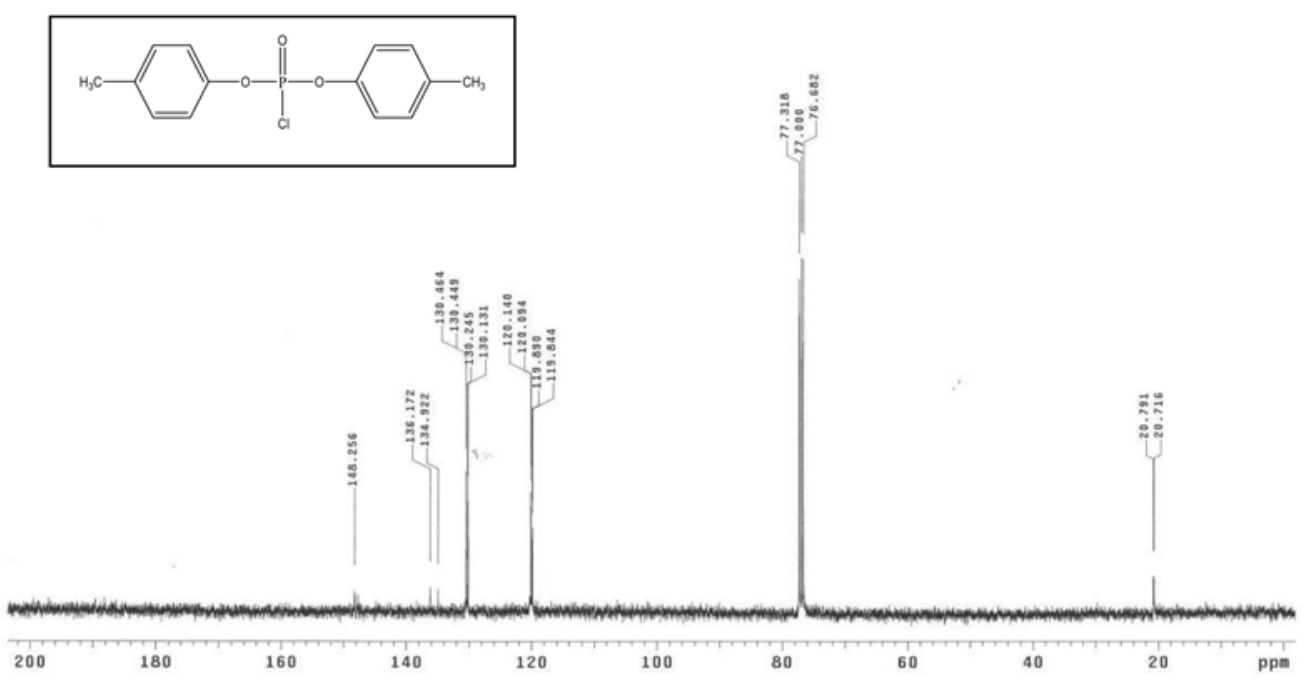

Figure S6. The ${ }^{13} \mathrm{C}$ - NMR spectrum of bis(4-methylphenyl) chlorophosphate. 


\section{Substrate: Bis (4-methylphenyl) chlorophosphate}

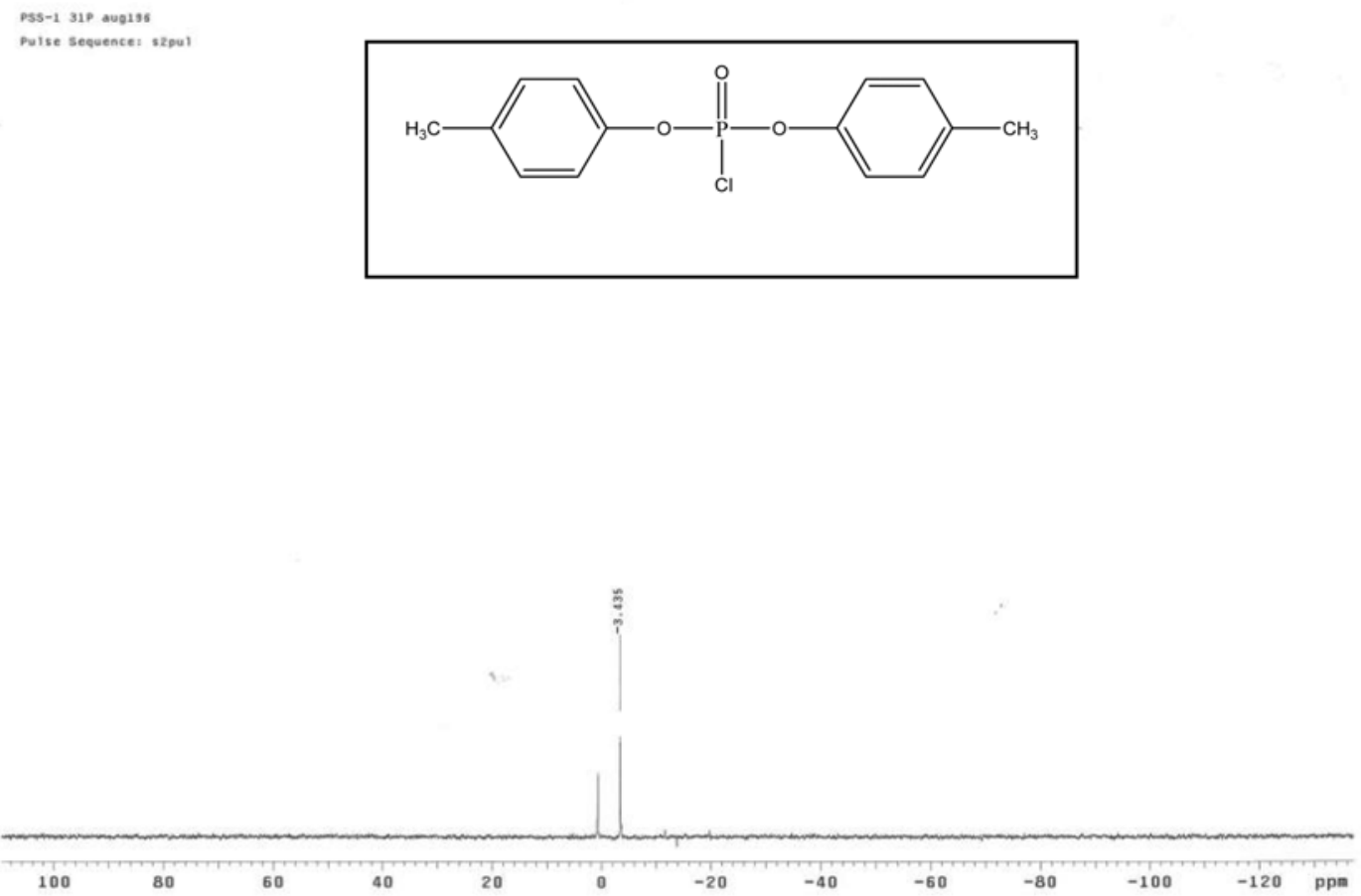

Figure S7. The ${ }^{31} \mathrm{P}-\mathrm{NMR}$ spectrum of bis(4-methylphenyl) chlorophosphate. 


\section{Substrate: Bis (4-methylphenyl) chlorophosphate}

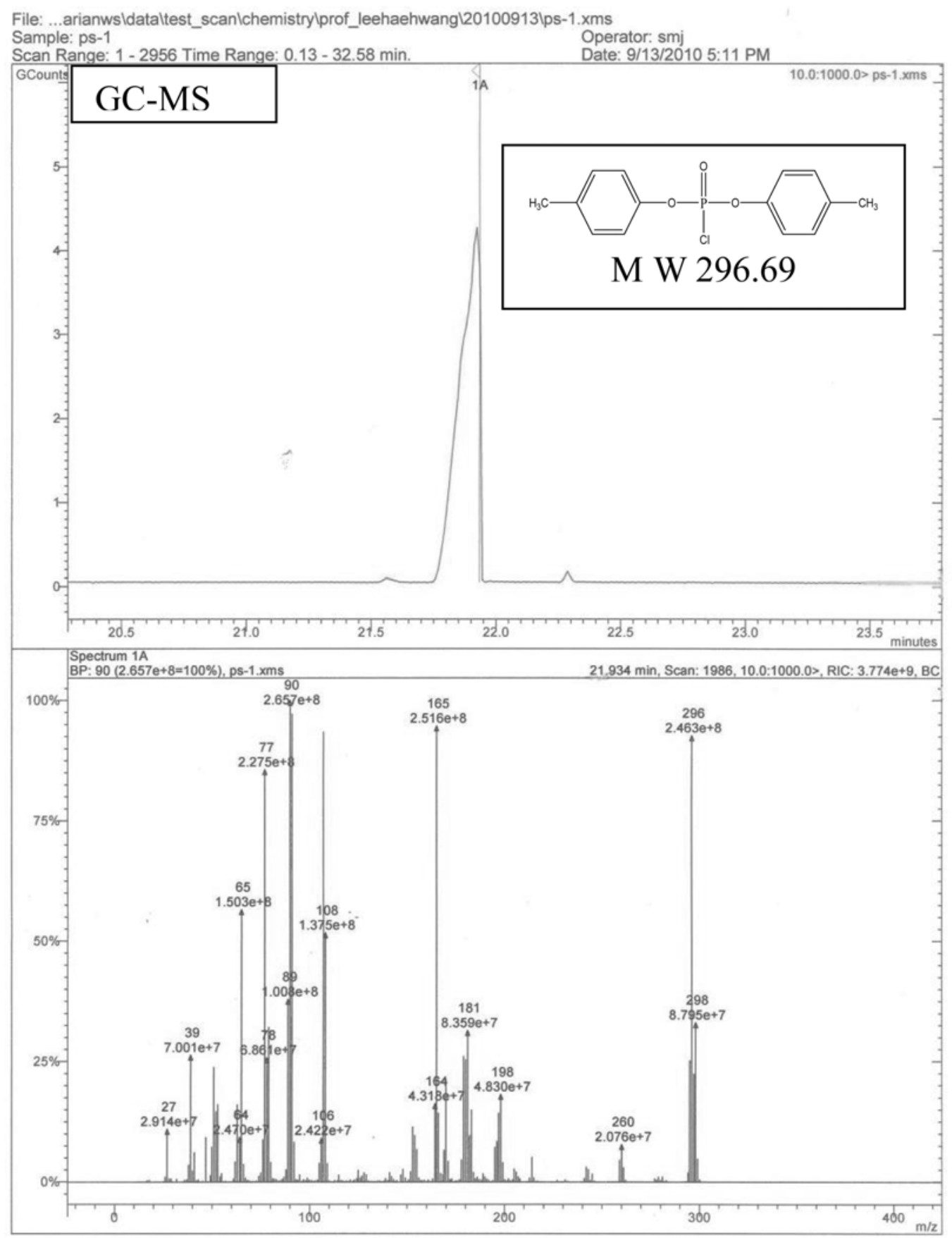

Figure S8. The GC-MS spectrum of bis(4-methylphenyl) chlorophosphate. 


\section{Substrate: Bis (3-methoxyphenyl) chlorophosphate}

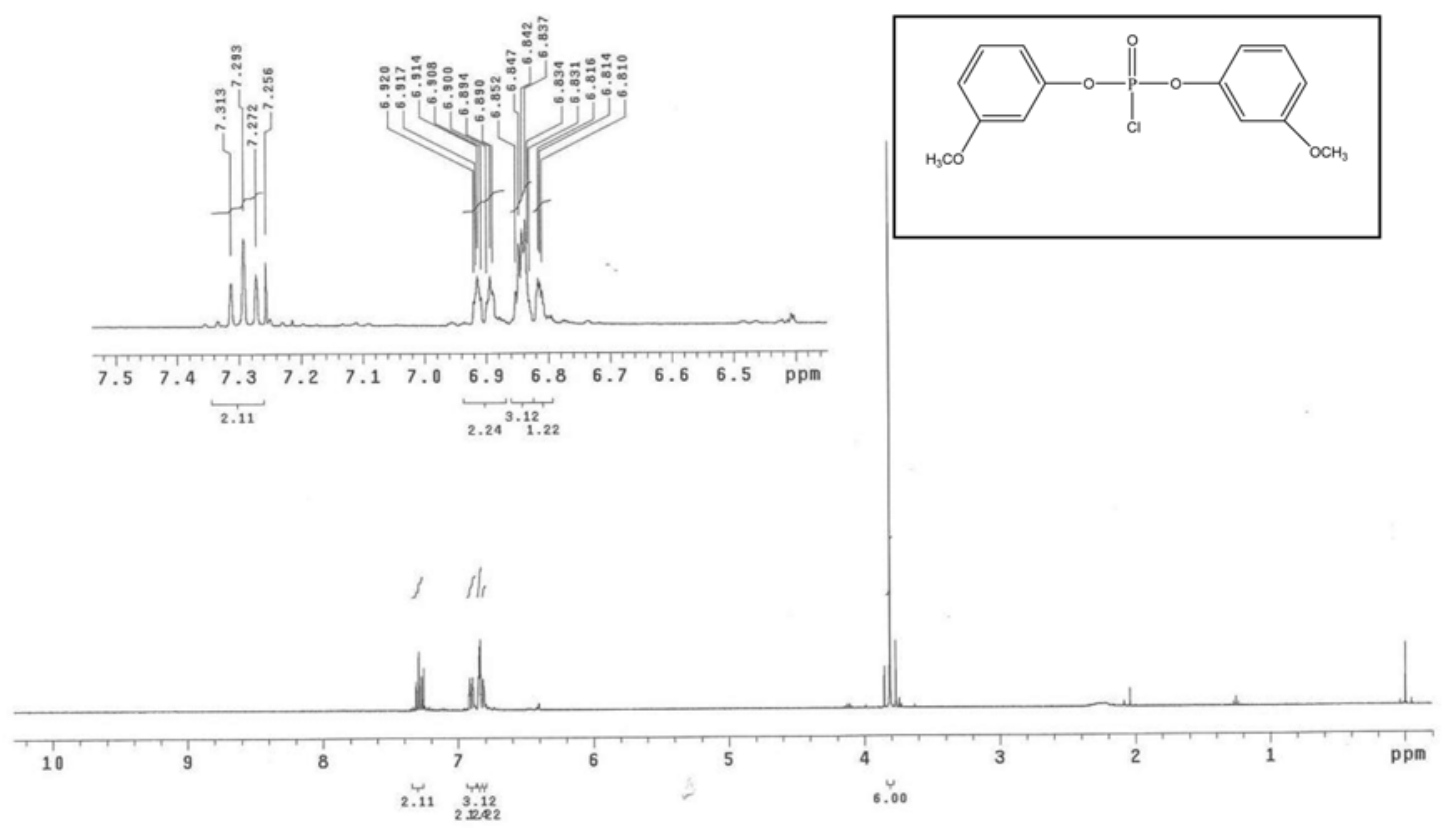

Figure S9. The ${ }^{1} \mathrm{H}-\mathrm{NMR}$ spectrum of bis(3-methoxyphenyl) chlorophosphate.

\section{Substrate: Bis (3-methoxyphenyl) chlorophosphate}

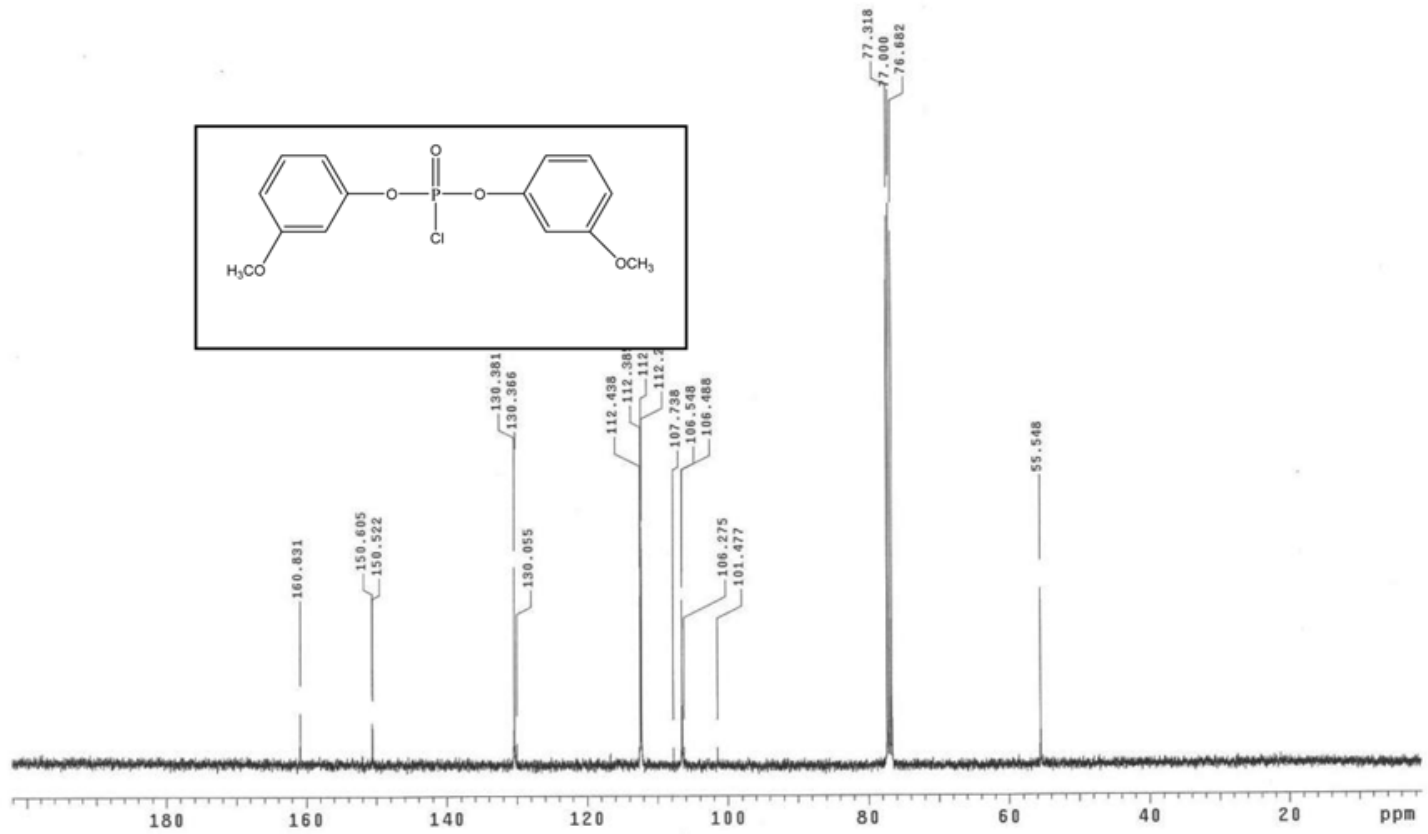

Figure S10. The ${ }^{13} \mathrm{C}-\mathrm{NMR}$ spectrum of bis(3-methoxyphenyl) chlorophosphate. 


\section{Substrate: Bis (3-methoxyphenyl) chlorophosphate}

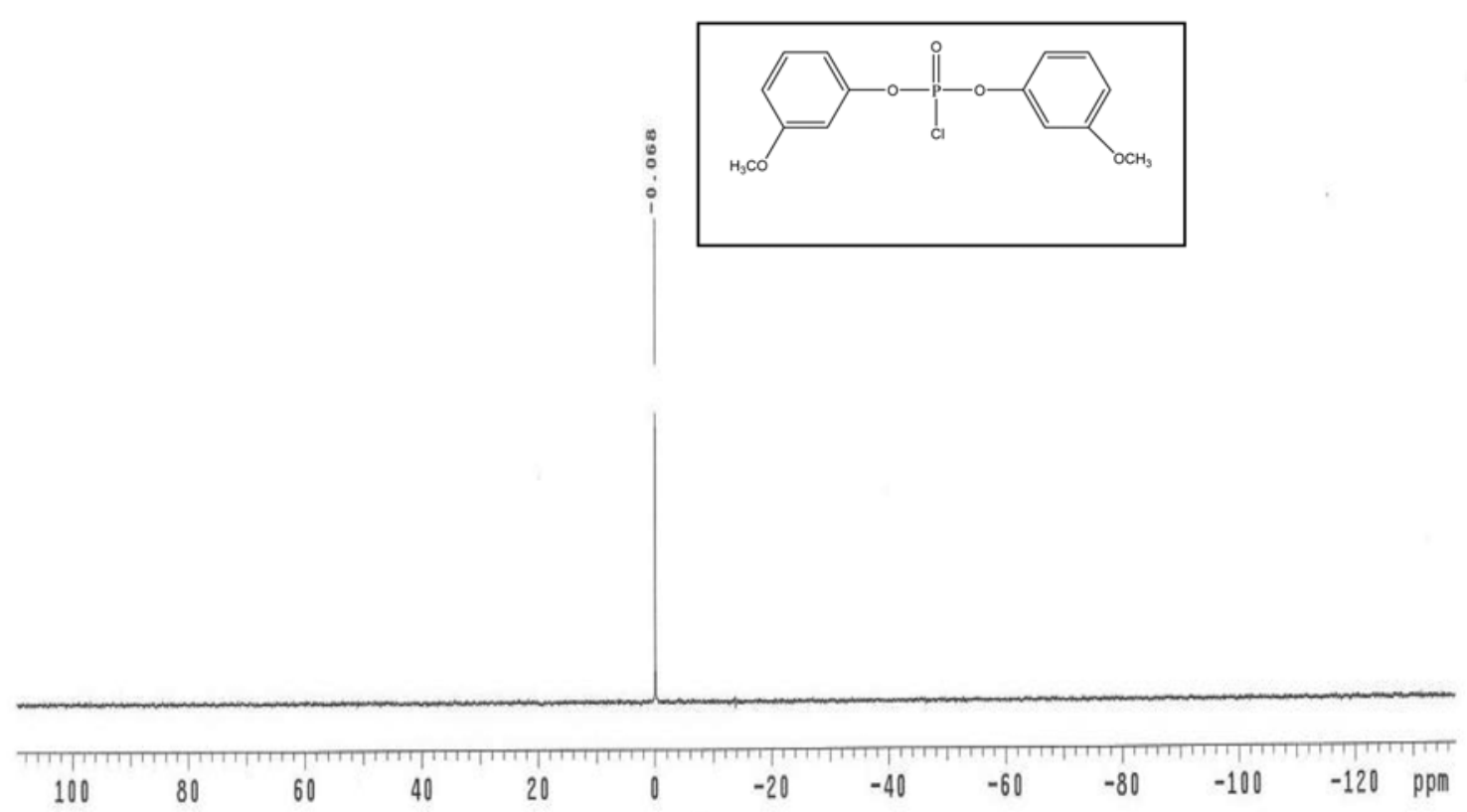

Figure S11. The ${ }^{31} \mathrm{P}-\mathrm{NMR}$ spectrum of bis(3-methoxyphenyl) chlorophosphate. 


\section{Substrate: Bis (3-methoxyphenyl) chlorophosphate}

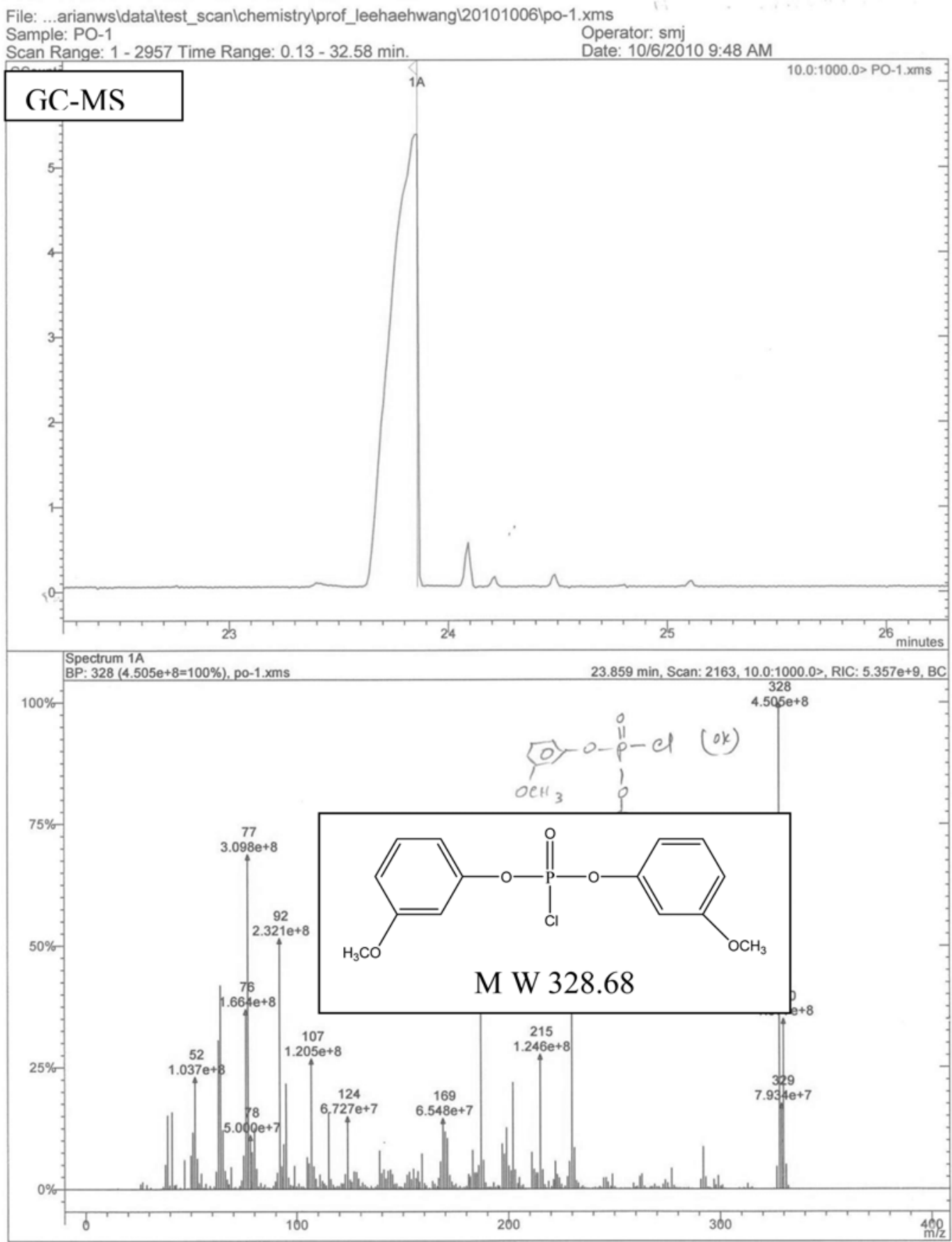

Figure S12. The GC-MS spectrum of bis(3-methoxyphenyl) chlorophosphate. 


\section{Substrate: Bis (3-methoxyphenyl) chlorophosphate}

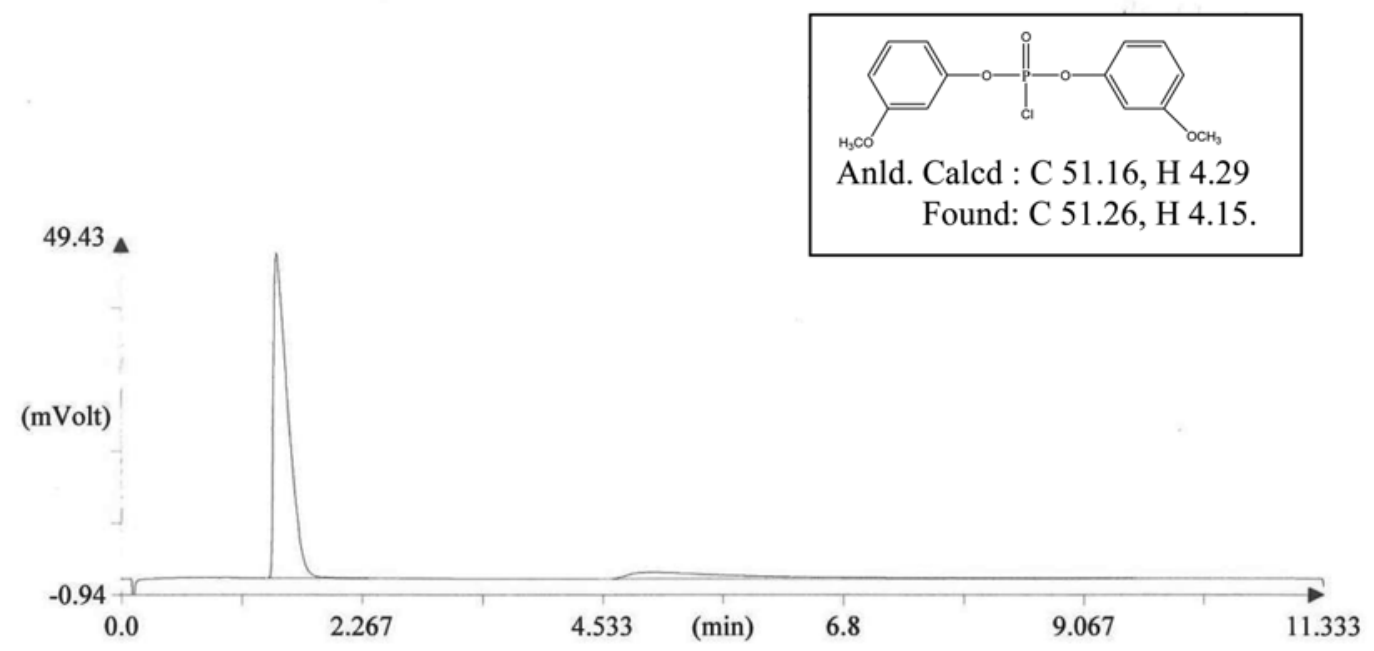

Operator ID:

Company name: inha

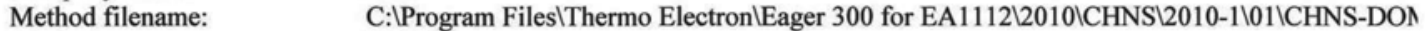

Method name: NCHS

Analysed: $\quad$ 2011-04-07 13:40

Printed: $\quad$ 2011-04-07 14:23

Elemental Analyser method:

Sampler method:

Sample ID: $\quad$ Po-2 (\# 23)

Analysis type: UnkNown

Chromatogram filename: B708.dat

Calibration method: K Factors

Sample weight: $\quad 1.78$

Protein factor: $\quad 6.25$

\begin{tabular}{lrrrrr} 
Element Name & Ret. Time & Area & BC & Area ratio & K f \\
\hline Carbon & 51.2634 & 88 & 4302639 & RS & 1.000000 \\
Hydrogen & 4.1513 & 300 & 746985 & RS & 5.760007 \\
Totals & 55.4147 & & 5049624 & .101
\end{tabular}

Figure S13. The elemental analysis (EA) of bis(3-methoxyphenyl) chlorophosphate. 
Product: $\left(\mathrm{C}_{6} \mathrm{H}_{5} \mathrm{O}\right)_{2} \mathrm{P}(=\mathrm{O})\left(\mathrm{NHC}_{6} \mathrm{H}_{4}-4-\mathrm{OCH}_{3}\right)$

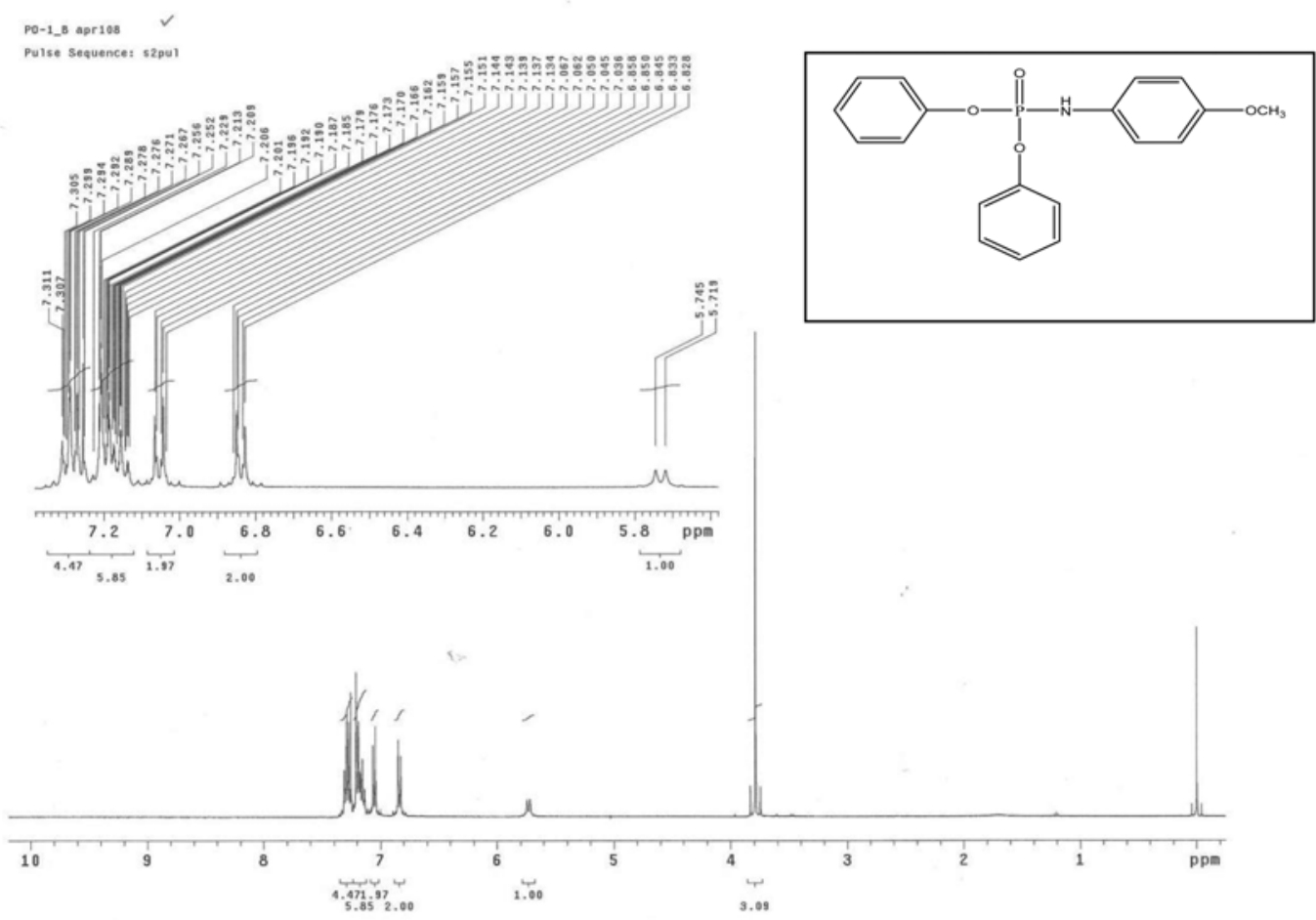

Figure S14. The ${ }^{1} \mathrm{H}$ - NMR spectrum of $\left(\mathrm{C}_{6} \mathrm{H}_{5} \mathrm{O}\right)_{2} \mathrm{P}(=\mathrm{O})\left(\mathrm{NHC}_{6} \mathrm{H}_{4}-4-\mathrm{OCH}_{3}\right)$.

Product: $\left(\mathrm{C}_{6} \mathrm{H}_{5} \mathrm{O}\right)_{2} \mathrm{P}(=\mathrm{O})\left(\mathrm{NHC}_{6} \mathrm{H}_{4}-4-\mathrm{OCH}_{3}\right)$
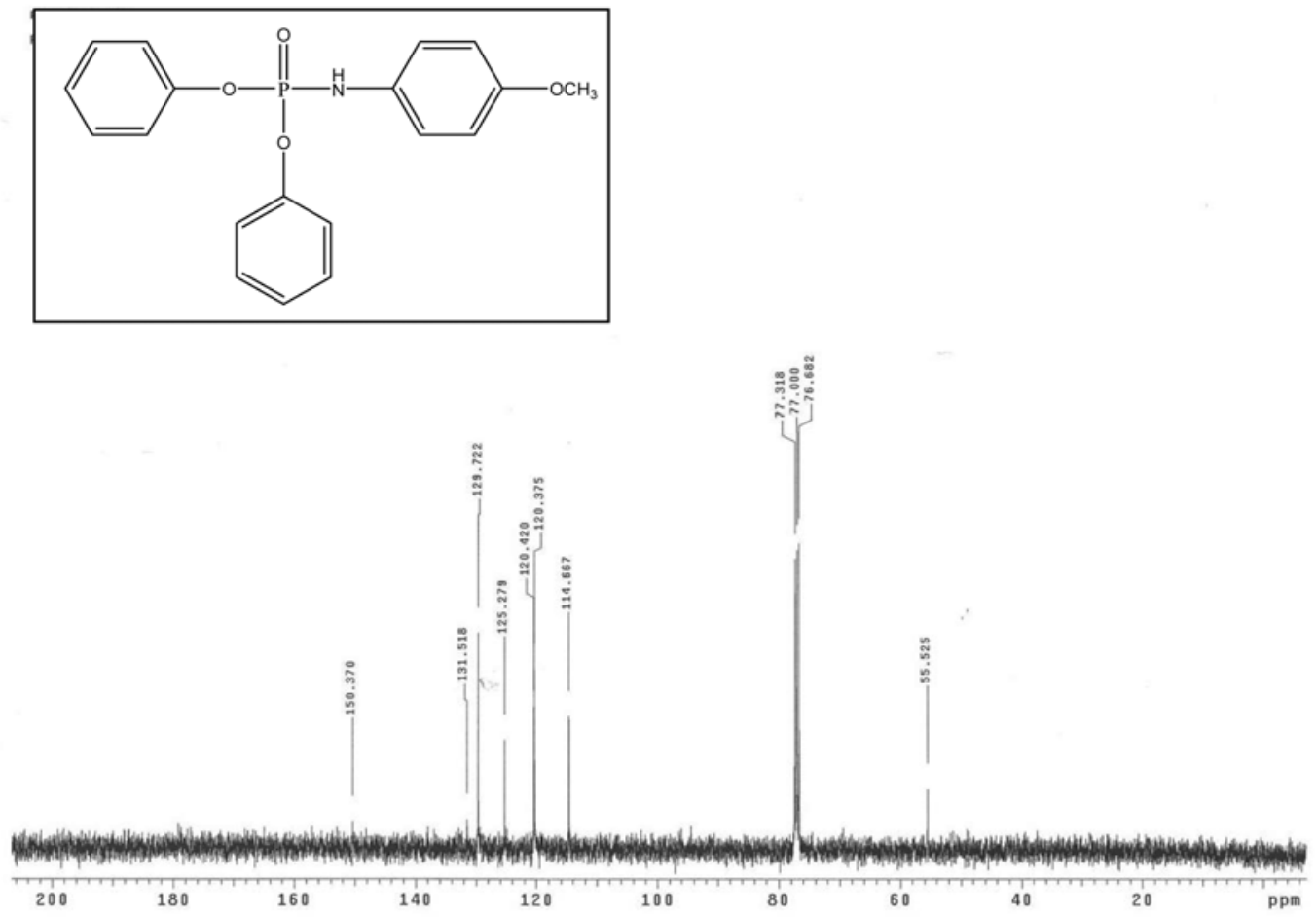

Figure S15. The ${ }^{13} \mathrm{C}$ - NMR spectrum of $\left(\mathrm{C}_{6} \mathrm{H}_{5} \mathrm{O}\right)_{2} \mathrm{P}(=\mathrm{O})\left(\mathrm{NHC}_{6} \mathrm{H}_{4}-4-\mathrm{OCH}_{3}\right)$. 


\section{Product: $\left(\mathrm{C}_{6} \mathrm{H}_{5} \mathrm{O}\right)_{2} \mathrm{P}(=\mathrm{O})\left(\mathrm{NHC}_{6} \mathrm{H}_{4}-4-\mathrm{OCH}_{3}\right)$}

P0-1_B 31P apriog

Pulse Sequence: s2pur

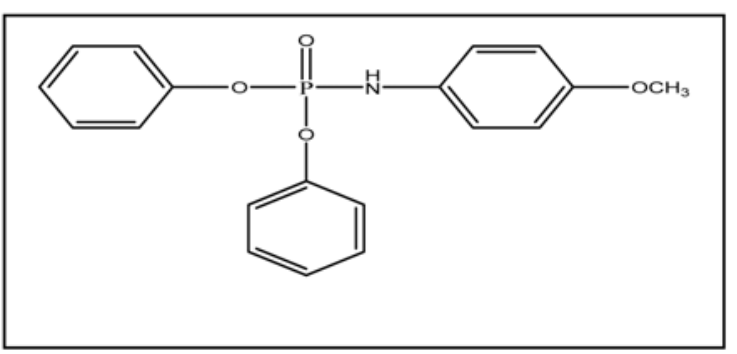

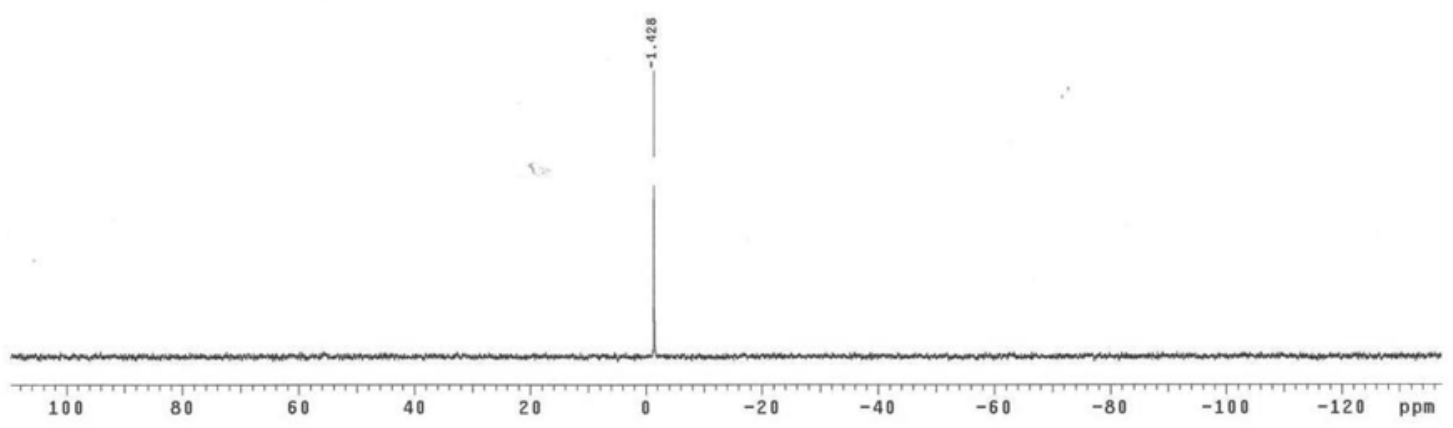

Figure S16. The ${ }^{31} \mathrm{P}-\mathrm{NMR}$ spectrum of $\left(\mathrm{C}_{6} \mathrm{H}_{5} \mathrm{O}\right)_{2} \mathrm{P}(=\mathrm{O})\left(\mathrm{NHC}_{6} \mathrm{H}_{4}-4-\mathrm{OCH}_{3}\right)$. 


\section{Product: $\left(\mathrm{C}_{6} \mathrm{H}_{5} \mathrm{O}\right)_{2} \mathrm{P}(=\mathrm{O})\left(\mathrm{NHC}_{6} \mathrm{H}_{4}-4-\mathrm{OCH}_{3}\right)$}

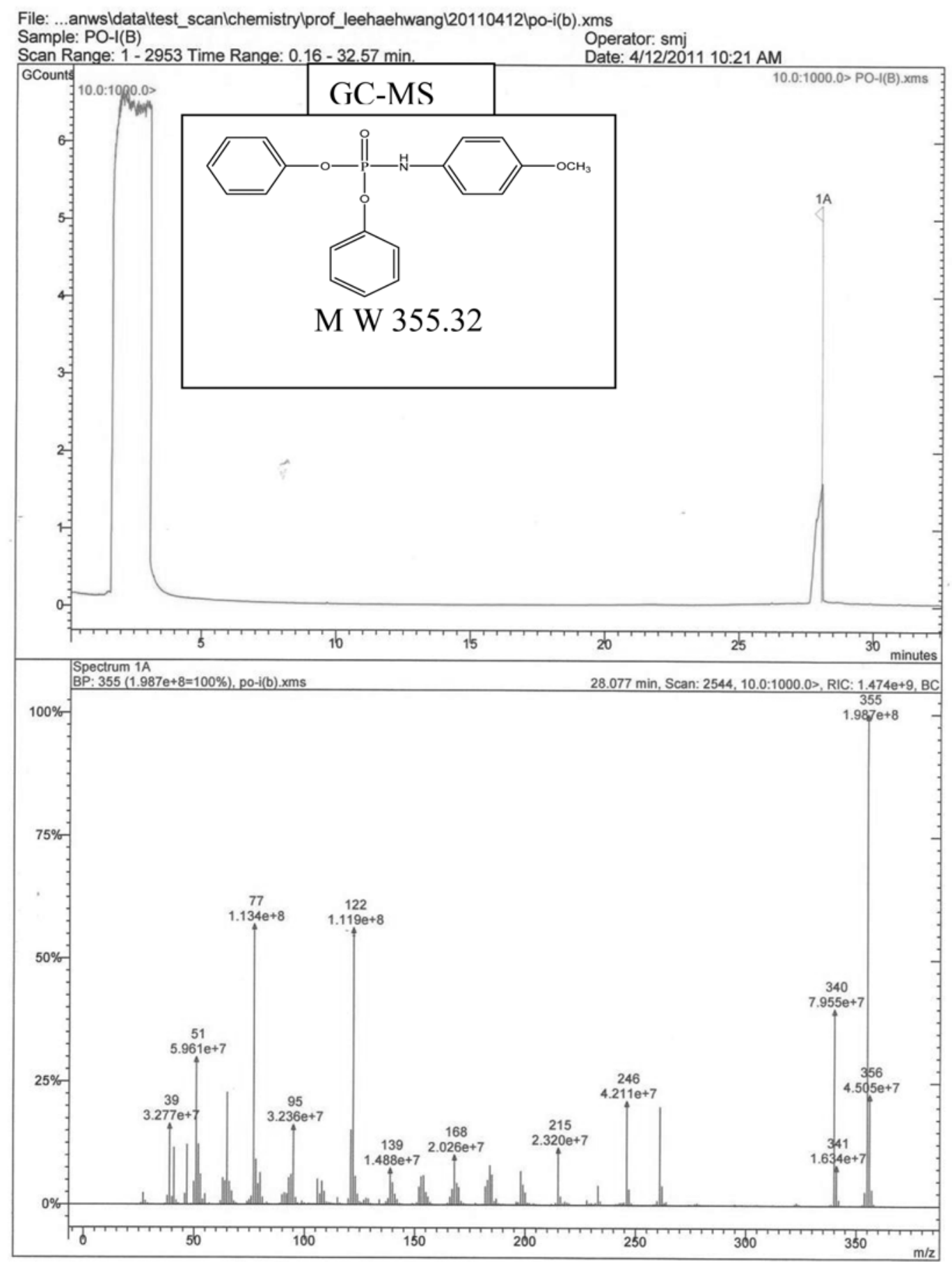

Figure S17. The GC-MS spectrum of $\left(\mathrm{C}_{6} \mathrm{H}_{5} \mathrm{O}\right)_{2} \mathrm{P}(=\mathrm{O})\left(\mathrm{NHC}_{6} \mathrm{H}_{4}-4-\mathrm{OCH}_{3}\right)$. 


\section{Product: $\left(\mathrm{C}_{6} \mathrm{H}_{5} \mathrm{O}\right)_{2} \mathrm{P}(=\mathrm{O})\left(\mathrm{NHC}_{6} \mathrm{H}_{4}-4-\mathrm{OCH}_{3}\right)$}

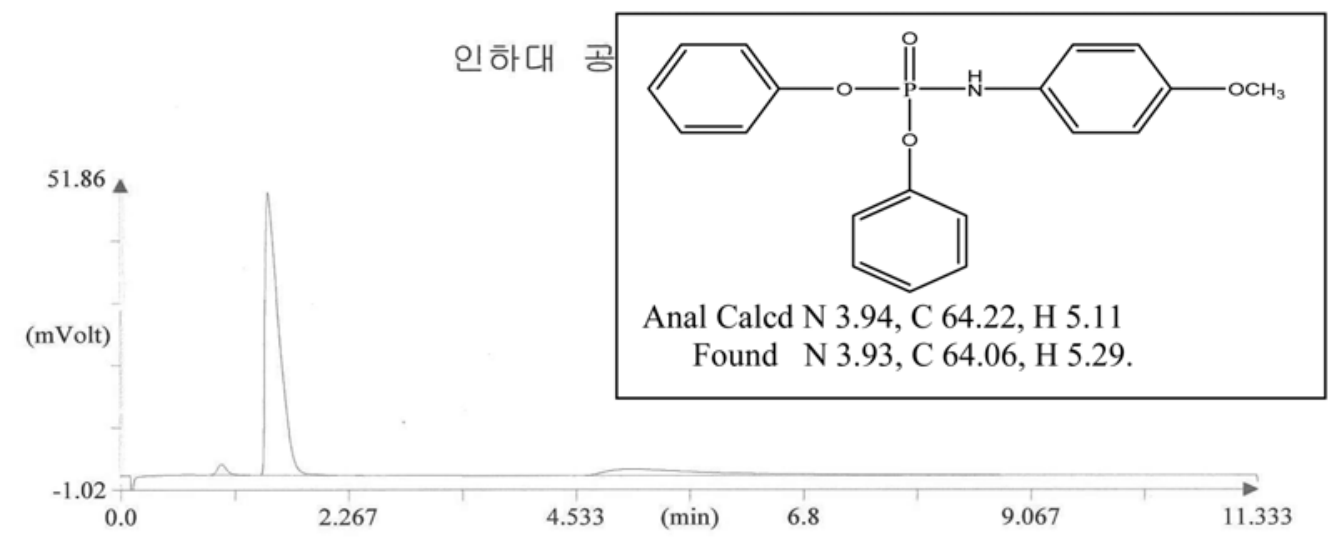

Operator ID:

Company name:

Method filename:

Method filenam

Method name:

Analysed:

Printed:

Elemental Analyser method:

Sampler method:

Sample ID:

Analysis type:

Chromatogram filename:

Calibration method:

Sample weight:

Protein factor:

inha

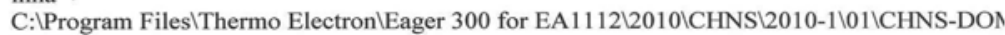
NCHS

2011-04-13 19:38

2011-04-14 11:24

PO-1(B) (\# 11)

UnkNown

B721.dat

K Factors

1.503

6.25

\begin{tabular}{|c|c|c|c|c|c|c|}
\hline Element Name & & Ret.Time & Area & $\mathrm{BC}$ & Area rat io & K f \\
\hline - - - & $\cdots \cdots$ & $\ldots \ldots$ & $\ldots \ldots$ & - & $\ldots \ldots$ & $\cdots$ \\
\hline Nitrogen & 3.9276 & 60 & 117010 & RS & 38.525280 & .198 \\
\hline Carbon & 64.0549 & 88 & 4507843 & RS & 1.000000 & .467 \\
\hline Hydrogen & 5.2914 & 306 & 893432 & RS & 5.045536 & .112 \\
\hline Tot a $1 \mathrm{~s}$ & 73.2738 & & 5518285 & & & \\
\hline
\end{tabular}

Figure S18. The elemental analysis $(E A)$ of $\left(\mathrm{C}_{6} \mathrm{H}_{5} \mathrm{O}\right)_{2} \mathrm{P}(=\mathrm{O})\left(\mathrm{NHC}_{6} \mathrm{H}_{4}-4-\mathrm{OCH}_{3}\right)$.

Table S1. Activation parametersa for the reactions of bis(phenyl) chlorophosphate with $\mathrm{X}$-anilines in $\mathrm{MeCN}$ at $35.0^{\circ} \mathrm{C}$

\begin{tabular}{|c|c|c|c|c|c|}
\hline Y & $X$ & $t /{ }^{\circ} \mathrm{C}$ & $\begin{array}{l}k_{2} \times 10^{4} \\
\left(\mathrm{M}^{-1} \mathrm{~s}^{-1}\right)\end{array}$ & $\begin{array}{c}\Delta H^{\#} \\
\mathrm{kcal} \mathrm{mol}^{-1}\end{array}$ & $\begin{array}{c}-\Delta S^{\#} \\
\text { cal } \mathrm{mol}^{-1} \mathrm{~K}^{-1}\end{array}$ \\
\hline \multirow{10}{*}{$\mathrm{H}$} & \multirow{3}{*}{ 4-MeO } & 55 & $136.2 \pm 0.3$ & \multirow{3}{*}{$6.7 \pm 0.2$} & \multirow{3}{*}{$47 \pm 1$} \\
\hline & & 45 & $97.4 \pm 0.2$ & & \\
\hline & & 35 & $65.9 \pm 0.2$ & & \\
\hline & \multirow{4}{*}{$\mathrm{H}$} & 65 & $14.3 \pm 0.2$ & \multirow{4}{*}{$7.6 \pm 1.0$} & \multirow{4}{*}{$49 \pm 3$} \\
\hline & & 55 & $8.91 \pm 0.03$ & & \\
\hline & & 45 & $5.53 \pm 0.03$ & & \\
\hline & & 35 & $4.43 \pm 0.02$ & & \\
\hline & \multirow{3}{*}{$4-\mathrm{Cl}$} & 55 & $1.25 \pm 0.01$ & \multirow{3}{*}{$7.3 \pm 0.4$} & \multirow{3}{*}{$54 \pm 1$} \\
\hline & & 45 & $0.823 \pm 0.003$ & & \\
\hline & & 35 & $0.568 \pm 0.007$ & & \\
\hline
\end{tabular}

${ }^{a}$ Calculated by the Eyring equation. ${ }^{b}$ Standard deviation 